\title{
Does Integration and Economic Policy Coordination Promote Business Cycle Synchronization in the EU?
}

\author{
Nikolaos Antonakakis*† Gabriele Tondl ${ }^{\ddagger}$
}

April 7, 2014

\begin{abstract}
Previous studies have discounted important factors and indirect channels that might contribute to business cycle synchronization (BSC) in the EU. We estimate the effects of market integration and economic policy coordination on bilateral business cycle correlations over the period 1995-2012 using a simultaneous equations model that takes into accounts both the endogenous relationships and unveils direct and indirect effects. The results suggest that (i) trade and FDI have a pronounced positive effect on BCS, particularly between incumbent and new EU members. (ii) Rising specialization does not decouple business cycles. (iii) The decline of income disparities in EU27 contributes to BCS, as converging countries develop stronger trade and FDI linkages. (iv) There is strong evidence that poor fiscal discipline of EU members is a major impediment of business cycle synchronization. (v) The same argument holds true for exchange rate fluctuations that hinder BCS, particularly in EU15. Since BCS is a fundamental prerequisite and objective in an effective monetary union, the EU has to promote market integration and strengthen the common setting of economic policies.
\end{abstract}

Keywords: Business cycle, synchronization, transmission, direct and indirect effect, FDI, trade, monetary union, EU

JEL codes: E30, E52, E62, F15, F42, F44

\footnotetext{
${ }^{*}$ Vienna University of Economics and Business, Department of Economics, Institute for International Economics, Welthandelsplatz 1, 1020, Vienna, Austria, e-mail: nikolaos.antonakakis@wu.ac.at, phone: $+43 / 1 / 313$ 36-4141, fax: +43/1/313 36-90-4141.

${ }^{\dagger}$ University of Portsmouth, Economics and Finance Subject Group, Portsmouth Business School, Portland Street, Portsmouth, PO1 3DE, United Kingdom, e-mail: nikolaos.antonakakis@port.ac.uk

${ }^{\ddagger}$ Vienna University of Economics and Business, Department of Economics, Institute for International Economics \& Research Institute for European Affairs, Welthandelsplatz 1, 1020, Vienna, Austria, e-mail: gabriele.tondl@wu.ac.at.
} 


\section{Introduction}

Business cycle synchronization (BCS) is an important prerequisite for the operation of a common monetary policy by the European Central Bank (ECB). Only if business cycles of the Euro members follow the same timing, direction and magnitude, can the ECB run an effective monetary policy. This is relevant for both the current and the prospective members of the Eurozone.

The question arises whether increased market integration and common or strongly coordinated economic policies promote BCS. The integration policy of the EU has led to a major increase of intra-EU trade and FDI and partly higher specialization (Fontagné et al., 1998; Badinger and Breuss, 2004; Pelkmans, 2006). While these linkages have become intensive in the EU15 already during the 1990s, the new EU12 countries have developed their trade and FDI relations with the EU15 fairly fast since the end of the 1990s, so that it has become their principal trading partner and investor (see discussion in Section 5). The EU introduced the European Exchange Rate Mechanism (ERM), that requests EU members to coordinate their monetary policies, and which was not only conceived as a pre-stage for EMU, but also intended to facilitate trade. It adopted a common monetary policy for the Eurozone members and has operated the Stability and Growth Pact (SGP) intended to force budgetary discipline among EU members, and to coordinate their fiscal policies. However, it was not always managed according to its strict intention. Finally, the EU has aimed to reduce income disparities among its members by its regional policy with some success.

The business cycle synchronization literature has argued, for similar or alternative set of (EU) countries, that the factors involved by this integration policy and economic policy coordination are determinants of the co-movement of business cycles. While there is an elaborated empirical literature on the effects of trade, coordinated exchange rate policies and sectoral similarities on BCS in the EU (see, for example Clark and van Wincoop, 2001; Siedschlag and Tondl, 2011; Crespo-Cuaresma et al., 2011, among others), the empirical literature has largely neglected the effects of FDI linkages, fiscal policy conditions, and income disparities. This study aims to fill this gap in the literature by examining the effect of these factors, in addition to the ones already established, as they are particularly important in the EU both as real achievements of integration as well as EU policy targets. Policy makers should know to which extent FDI linkages determine business cycle synchronization, whether the declared objective of EU's regional policy, income convergence, serves indirectly to achieve more synchronization, and if more coordinated fiscal policies are desirable in this context.

We shall look at the synchronization of bilateral business cycles within the EU27. As an indicator of business cycle synchronization the correlation of annualized quarterly HP-filtered real GDP series over 5-year rolling windows is employed. Moreover, we include in our examination the effect of bilateral trade and FDI, bilateral exchange rate volatility, bilateral differences in government deficits, dissimilarities in economic specialization and income differences on business cycle correlations. We conjecture that the relation between these factors and business cycle correlations differ among countries in the EU15, EU15-newEU12 (i.e. the group comprising country pairs between the incumbent EU15 members and the new EU12 members of the EU27), in the Euro Area (EA), among the Core and Periphery of the EA, and among country pairs in the total EU27. While in the EA and in EU15 we find fairly similar economies that have experienced economic integration for a considerable amount of time, country pairs in EU15-newEU12 are still less integrated and show considerable differences in economic development. The EU27 and the EA are confronted with both similar and quite dissimilar economies. Our period of investigation covers business cycle correlations over the period 1995-2012 (14 observations of 5-year rolling windows) that permits us to examine up to 325 cross-sections totalling 4550 observations in the full sample based on a panel data set. 
The hypothesized relations between business cycles synchronization and the suggested explanatory factors are assumed to be simultaneously/endogenously determined. For instance, trade, on the one hand, will foster business cycle correlations but, on the other hand, more synchronized business cycles can also foster trade between countries. This simultaneity may arise as well with the additional endogenous variables employed in this study. To account for the manifold and simultaneous relations, we use a model of simultaneous equations as employed also in (Imbs, 2004, among others). This permits us to observe both the direct and indirect effects of the explanatory variables. In contrast to the existing applications, we permit for a more elaborated set of endogenous relations. Thus we can find additional interesting indirect effects not yet discovered in the literature.

In our descriptive analysis we observe that business cycle synchronization has increased in the EU27, however, it is still distinctly lower than that in the Euro Area and the EU15. Our estimations show that the established trade integration and FDI linkages are key factors promoting convergence of business cycles in the EU. However, we argue that only vertical FDI contributes to BCS. The increasing specialization does not - in contrast to the previous studies - decouple business cycles. The reduction of exchange rate volatility, partly by EMU membership, leads to increased business cycle synchronization, and is the most important determinant for the achieved high BCS in the EU15. In addition, exchange rate fluctuations are clearly caused by individual business cycles and sector specific developments, as well as inflation and credit differentials. The reduction of divergent fiscal policies has contributed to BCS in the EU27, however, the newly arising great imbalances in government deficits, especially between the peripheral and Eurozone core countries, have become a decoupling factor of business cycles in the Eurozone. Interestingly, we find that governments budget deficits spreads are always associated with large differences in government efficiency and with income gaps. In addition, our results suggest that the reduction of income disparities in the EU27 is an important factor of stronger BCS. Among the most important indirect effects are: (i) the effect of FDI on business cycle synchronization via its stimulation of trade, (ii) the positive effect of trade contributing to the reduction of income disparities, but the negative effect of government deficits on the later. Thus, apparently, the EU's integration policy fostering trade and FDI linkages has an important impact on BCS. Coordinated monetary policies, rule bound, and strict fiscal policies promote BCS. These policies therefore indirectly contribute to the functioning of the Eurozone with its common ECB policy.

The rest of the paper is structured as follows: Section 2 proposes our hypotheses and discusses the findings in the literature. Section 3 presents the model specification for our estimations. Section 4 describes the variables, section 5 provides some empirical facts, section 6 presents the results and section 7 concludes.

\section{Theoretical aspects, findings in the empirical literature and hypotheses}

We consider bilateral correlations of cyclical components of real GDP as an indicator of BCS in the EU, and examine six potential determinants of BCS, namely, bilateral trade relations, FDI linkages, monetary policy coordination, fiscal budget imbalances, differences in specialization, and income disparities. We postulate that the factors determining BCS in the EU can also explain each other, and thus a reverse causality with BCS is possible. Acknowledging this endogeneity in a simultaneous equations model, we can posit the following additional hypotheses: (i) we postulate that business cycle synchronization determinants can be potentially influenced by other factors, that so far have not been explored rigorously, and (ii) that those determinants 
can indirectly influence BCS via other channels.

Our first hypothesis is that trade integration serves as a transmission channel of business cycles in the EU. We are interested to learn about the role of EU's integration policy for BCS in different parts of the EU. Frankel and Rose (1998) were among the first to argue that trade linkages would result in increased BCS, Clark and van Wincoop (2001), Siedschlag and Tondl (2011) and Rana et al. (2012) have verified the positive effect for the EU15, Gouveia and Correia (2013) for the Euro Area 12 countries, and Crespo-Cuaresma et al. (2011) for the EU25 countries. ${ }^{1}$ The idea is that demand shocks are transmitted between countries via trade relations, thus leading to a synchronized increase or decrease of business cycles.

We propose that trade itself is increased by fixed exchange rates (as argued in Frankel and Rose, 1998, rooted in the ideas of McKinnon, 1963), through specialization (as found in Siedschlag and Tondl, 2011, for EU15), FDI linkages and similarity in income levels. Trade flows in turn could induce increased specialization of production, thus affecting business cycle correlation indirectly. If stronger trade linkages are associated with increased inter-industry specialization across countries, and industry-specific shocks are important in driving business cycles, then business cycle synchronization might be expected to decrease (Kose et al., 2003).

Second, we consider that business cycle transmission may arise because of FDI linkages between economies. FDI takes place due to different motives. It may be of the type of marketseeking FDI in the EU. A financial services affiliate of a UK company operating in another EU15 country or in the new EU12 may serve as a typical example. This type of FDI wishes to exploit foreign markets in order to diversify the business. Companies may even search FDI destinations with a different growth trend to diversify risk. Following Devereux and Yetman (2010) we can argue that the performance of the affiliate will affect the mother company, either through registered profits or losses which will lead to more or less investment activity at home. A particular example is financial sector FDI. In case of a crisis and credit defaults in the host economy, the mother company may encounter solvency problems which in turn affect the credit volume in the home country (Kröger et al., 2010). Thus FDI can propagate shocks. In summary, with market seeking FDI, the business activity of the mother company will be affected by the performance of the affiliate either with the same cyclical or anti-cyclical pattern, depending on how synchronized economic growth is in the host economy. Consequently, market-seeking FDI either promotes or hinders business cycle synchronization. The second major type of FDI is vertical FDI. Here, a part of the production process is transferred to another country in concern to save labour cost or other costs. The affiliate and the mother company are linked intensively by trade flows of intermediates. For instance, during the recent economic crisis, the decline in demand for automotives in Germany was translated into a falling demand for components produced in German owned affiliates in Slovakia. Vertical FDI may thus constitute a major channel for business cycle transmission. In a different vein, Backus et al. (1992) and Fidrmuc et al. (2010) argue that FDI can be based on the comparative advantage of the host country, and thus enforce specialization that ultimately decreases synchronization.

The empirical literature on the role of FDI - and not other financial linkages - on business cycle synchronization remains limited and is rather inconclusive. Jansen and Stokman (2014) examine the relationship between FDI and business cycle synchronization between 1982 and 2011 for eight industrialized countries, and find that more synchronized business cycles are associated with stronger FDI relations over the period 1995-2011, but not before 1995. Dées and Zorell (2012) show that it still remains difficult to disentangle a direct relationship between bilateral FDI linkages and output correlations. While no such significant direct relationship exists for the

\footnotetext{
${ }^{1}$ Fidrmuc (2004) and Fontagné and Freudenberg (1999) test explicitly the impact of intra-industry trade to promote BC synchronization.
} 
OECD countries, the relation becomes significantly positive for the EU25 countries. Imbs (2004, 2006) finds a positive direct relation between FDI linkages and output correlation in a worldwide sample. In addition, Imbs (2004) and Kalemli-Ozcan et al. (2003) find that FDI affects business cycle synchronization indirectly via its effects on specialization. Last but not least, Hsu et al. (2011) argues that FDI serves as a channel of international business cycle transmission that is equally important as the channels of trade and monetary policy. ${ }^{2}$

Given that FDI has become important within the EU15 as well as between the EU15 and the new EU12 countries, and that there is limited and inconclusive literature, we are interested to examine whether FDI has an impact on business cycle correlations in different country blocks of the EU, and thus whether integration policy which intends to promote European-wide internationalization of production sites serves BCS. Furthermore, since the literature does not consider rigorously the potential endogeneity of FDI, and since we wish to disentangle between the different types of FDI so as to shed light on the conflicting results in the literature, we shall model the determinants of FDI and its indirect effects explicitly in our simultaneous equations approach. In particular we shall consider the effect of FDI on trade, specialization and income disparities. As an indicator for FDI linkages we consider the sum of FDI stocks between country-pairs related to their GDP.

Third, we wonder whether a common monetary policy, as within the Eurozone, or coordinated monetary policies, if central banks pursue similar interest rate policies, as in the case of prospective members which adhere to the ERM, enforce BCS or have decoupling effects. This policy will introduce time-equivalent expansionary or restrictive effects on economic activity and may lead to similar developments in business cycles. This effect was observed in the run-up stage of EMU (Artis and Zhang, 1997). However, in the case of poor BCS, a common monetary policy may even increase diverging trends, and an individual exchange rate and monetary policy may better contribute to BCS (Siedschlag and Tondl, 2011). Moreover, as argued in McKinnon (1963) and found in Rose (2000), with fixed exchange rates the indirect effect is that more stable exchange rates promote trade. As an indicator for coordinated monetary policy we consider the exchange rate volatility between country-pairs. Given that the members of the Eurozone have grown in number over the past decade, we will benefit from significant variation in the data both across our bilateral cross-sections as well as over time.

Fourth, a similar argument can be raised with fiscal policy conditions, common deficit rules or common stimulation packages, as during the recent economic crisis and the common consolidation efforts thereafter. This may foster BCS, but less fiscal policy differences across EU countries may also serve to bring diverging business cycles closer to each other, a point made e.g. by Clark and van Wincoop (2001). In practice we find a significant degree of variation in fiscal policies among EU members despite the SGP. Thus we are interested in whether similar or different fiscal conditions contribute to BCS in the EU. We consider the bilateral difference in budget deficits. Empirical studies generally find that, fiscal policy coordination or similar

\footnotetext{
${ }^{2}$ Studies that use alternative measures of financial integration provide conflicting results. For instance, Jones and Witte (2011) find that financial integration has a significant negative effect on business cycle synchronization between the new member states of the EU and the euro area; Kalemli-Ozcan and Papaioannou (2009) find that a higher degree of financial integration is associated with less synchronized output cycles for a sample of 20 developed countries over the period 1978-2007; Kalemli-Ozcan et al. (2013) based on a panel data set for 18 rich economies over the 1978 to 2006 period identify a strong negative effect of banking integration on output synchronization, conditional on global shocks and country-pair heterogeneity; Cerqueira and Martins (2009) using data for 20 OECD countries from 1970 to 2002 find a negative and significant effect of financial openness on BCS. On the other hand, Akin (2012) who examines the determinants of real GDP correlations for 51 countries including 27 emerging markets over the period 1970-2008, finds no significant effect on business cycle synchronization on average; a negative effect for developed country pairs, and developed and emerging country pairs; and a positive effect on BCS for emerging markets.
} 
budget conditions, based on alternative proxies, generally lead to increased business cycle synchronization in the EU (see, for instance, Clark and van Wincoop, 2001; Darvas et al., 2005; Camacho et al., 2006; Artis et al., 2008; Furceri, 2009; Crespo-Cuaresma et al., 2011; Hauge and Skulevold, 2012).

Fifth, in accordance with the arguments of Kenen (1969), the literature on business cycle synchronization has also highlighted the importance of sectoral similarity (e.g. Imbs, 2004, 2006; Clark and van Wincoop, 2001; Inklaar et al., 2008). Countries with similar economic structures are more likely to be affected by similar demand shocks, while countries with dissimilar structures will watch a different timing of demand shocks. Sectoral dissimilarity between countries is supposed to result in different business cycles. As found in Siedschlag and Tondl (2011), specialization has also an indirect positive effect via trade. In this study we also explore the indirect effect of specialization on BCS via the FDI channel.

Finally, we are interested in seeing whether income differences in the EU have an effect on business cycle synchronization. Countries with very different per capita incomes are likely to have different economic policies and different institutional frameworks. Empirically, this point has hardly been investigated. Louis and Tozman (2010) found that countries in the same income group are more likely to show similar business cycles. ${ }^{3}$ Since the reduction of income disparities is a declared objective of the EU pushed by its heavily funded regional policy, we are interested in exploring whether the reduction of income disparities in the EU also contributes to business cycle synchronization. Furthermore, we expect income disparities to determine FDI flows, trade intensity, specialization and budget deficit differentials, and thus to produce indirect effects on BCS. Importantly, we consider the endogeneity of income differences explicitly in our model, and examine in a Heckscher-Ohlin spirit whether trade reduces income disparities and what is the role of mounting budget deficit conditions among EU countries.

The effects of the direct and indirect channels will be evaluated according to the methodology discussed in the following section.

\section{Model specification}

We build on Imbs (2004) and follow Siedschlag and Tondl (2011) and estimate a system of simultaneous equations based on a panel data set which, however, is far more complex than that in previous studies. The bilateral correlation of business cycles is explained by six variables which are all considered to be endogenous, so that each is modelled within the system separately. In this way we can examine a variety of diverse indirect effects, that have been so far overlooked in the literature. Since each variable is itself explained by two to six other endogenous variables plus exogenous variables, the variables are very well defined by this complexity. This is confirmed by a high explanatory power of the estimations, as we shall see below.

We estimate the proposed effects in the following simultaneous equations model based on a panel data set in different EU samples, namely, the EU15, EA11, Core Vs Periphery, EU15newEU12 and the full sample of EU27.

\footnotetext{
${ }^{3}$ Recently, Canova et al. (2012) examined whether three institutional changes (the Maastricht Treaty, the creation of the ECB and the Euro changeover) affect business cycles in Europe and found that the process of real convergence predates the three institutional changes
} 


$$
\begin{aligned}
C O R R Y_{i j t}= & \alpha_{1} F D I_{i j t}+\alpha_{2} T R A D E_{i j t}+\alpha_{3} G O V D E F_{i j t}+\alpha_{4} E X C H_{i j t}+\alpha_{5} S P E C_{i j t} \\
& +\alpha_{6} D G D P P C_{i j t}+\alpha_{7} I_{1 i j t}+\mu_{1 i j}+\lambda_{1 t}+\tau_{1 i j t}+\varepsilon_{1 i j t} \\
F D I_{i j t}= & \beta_{1} C O R R Y_{i j t}+\beta_{2} T R A D E_{i j t}+\beta_{3} S P E C_{i j t}+\beta_{4} D G D P P C_{i j t}+\beta_{5} I_{2 i j t} \\
& +\mu_{2 i j}+\lambda_{2 t}+\tau_{2 i j t}+\varepsilon_{2 i j t} \\
T R A D E_{i j t}= & \gamma_{1} C O R R Y_{i j t}+\gamma_{2} E X C H_{i j t}+\gamma_{3} S P E C_{i j t}+\gamma_{4} F D I_{i j t}+\gamma_{5} D G D P P C_{i j t} \\
& +\gamma_{6} I_{3 i j t}++\mu_{3 i j}+\lambda_{3 t}+\tau_{3 i j t}+\varepsilon_{3 i j t} \\
S P E C_{i j t}= & \delta_{1} T R A D E_{i j t}+\delta_{2} F D I_{i j t}+\delta_{3} I_{4 i j t}+\mu_{4 i j}+\lambda_{4 t}+\tau_{4 i j t}+\varepsilon_{4 i j t} \\
G O V D E F_{i j t}= & \zeta_{1} C O R R Y_{i j t}+\zeta_{2} D G D P P C_{i j t}+\zeta_{3} I_{5 i j t}+\mu_{5 i j}+\lambda_{5 t}+\tau_{5 i j t}+\varepsilon_{5 i j t} \\
E X C H_{i j t}= & \eta_{1} C O R R Y_{i j t}+\eta_{2} G O V D E F_{i j t}+\eta_{3} D G D P P C_{i j t}+\eta_{4} S P E C_{i j t}+\eta_{5} I_{6 i j t}+\mu_{6 i j} \\
& +\lambda_{6 t}+\tau_{6 i j t}+\varepsilon_{6 i j t} \\
D G D P P C_{i j t}= & \theta_{1} T R A D E_{i j t}+\theta_{2} G O V D E F_{i j t}+\theta_{3} F D I_{i j t}+\theta_{4} I_{7 i j t}+\mu_{7 i j}+\lambda_{7 t}+\tau_{7 i j t}+\varepsilon_{7}(j ; t)
\end{aligned}
$$

where $i, j$ and $t$ are the index country pairs $(i, j)$ in period $t$, and $\varepsilon$ is the error term. Vectors $I_{k i j}$, where $k=1, \ldots, 7$, include the exogenous variables that are employed in the system to achieve identification, and $\mu_{k i j}, \lambda_{k t}$ and $\tau_{k i j t}$, where $k=1, \ldots, 7$, are the country-pair fixed-effects, time fixed-effects and country-pair time-trends, respectively. ${ }^{4}$

As it is often unrealistic to expect the equation errors in our system to be uncorrelated, we employ a seemingly unrelated regression (SUR) system approach proposed by Zellner (1962). The SUR model is estimated using the feasible generalized least squares (FGLS) method, which is essentially a two-step procedure; in the first step we estimate the parameters of our system by ordinary least squares, and use the residuals obtained from this step to estimate the disturbance terms' variances and covariances in the second step.

$C O R R Y_{i j t}$ is the Fisher's $z$-transformation of correlations of annualized quarterly HP filtered $\log$ real GDP series between country $i$ and $j$. The Fisher's $z$-transformation is used in order to achieve normality in the distribution of the correlation coefficients, as the (Pearson) correlation coefficients are bounded at [-1,1] (see Inklaar et al., 2008). $F D I_{i j t}$ denotes FDI stocks between country-pairs related to the sum of their GDP; $T R A D E_{i j t}$ is the external trade between the two countries related to the sum of their GDP; GOVDEF $F_{i j t}$ is the differential in general government deficit between the two countries as an indicator for fiscal policy coordination; $E X C H_{i j t}$ refers to the volatility of the bilateral exchange rate as an indicator for the presence or absence of a common monetary policy regime; $S P E C_{i j t}$ is an index of similarity in sectoral structures between country-pairs , and $D G D P P C_{i j t}$ refers to bilateral differences in economic development.

In addition to the principal equation, the system consists of six auxiliary equations which capture the simultaneity contained in equation (1). In equation (2), bilateral FDI is explained by $C O R R Y_{i j t}$, the correlation of business cycles, $T R A D E_{i j t}$, the bilateral trade share, $S P E C_{i j t}$, differences in specialization, $D G D P P C_{i j t}$, the differences in per capita income, and a set of exogenous variables among them wage differences $(W A G E)$. This should permit us to find out to what extent FDI follows motives of risk diversification (CORRY), of comparative advantages $(S P E C)$, and whether FDI goes to differently developed markets (DGDPPC, WAGE).

Equation (3) explains trade by the correlation of business cycles, exchange rate volatility, similarity of economic structures, intensity of FDI linkages between partners, differences in economic development and a set of exogenous variables, among them, institutional variables

\footnotetext{
${ }^{4}$ For the system to be identified it is necessary that for each endogenous variable in an equation an equal number of exogenous variables differently from the exogenous in the same equation is present in the other equations. Thus each equation requires a different set of exogenous variables (Wooldridge, 2006).
} 
differences in regulatory quality, $R E G$, and rule of law, $R O L$. This should permit us to examine whether common monetary policy strengthens trade flows (negative coefficient of $E X C H$ ), whether trade is of inter- or intra- industry type (positive or negative coefficient of SPEC and $D G D P P C$ ), and whether FDI is enforcing trade so that we can assume the presence of vertical FDI.

Equation (4) explains specialization by the bilateral trade share, intensity of FDI linkages, and a set of exogenous variables, among them the sum of per capita income level of the partners, $S G D P P C$, and the differential of institutional quality indicators $(P O L, R E G, A C C)$. We assume that specialization increases with trade and FDI intensity, and that it mirrors differences in economic development.

Equation (5) posits that government deficit differentials are explained by the correlation of business cycles, differences in economic development, $D G D P P C$, and exogenous variables, among them, the long-term interest rate differentials, $L I N T$, and the differentials in government efficiency, GOVEFF. We postulate that large differences in fiscal conditions in the EU are invoked by different business cycles, appear between partners with different lending costs, they are more pronounced with unequally developed EU countries and with larger differences in government efficiency. In other words, we expect poorer EU member states to have higher government deficits.

Moving to Equation (6), the volatility of the bilateral exchange rates is determined by the correlation of business cycles, specialization, government deficit differentials, differences in economic development and a set of exogenous variables, namely, inflation differentials, INFL, short-term interest rate differentials, SINT, and domestic credit differentials, DOMCRED. We expect that larger exchange rate volatility differentials appear between country-pairs with de-synchronized business cycles, increased specialization, with larger differences in government budget deficit, inflation, interest rates and domestic credit, and with differences in economic development.

Finally, Equation (7) describes differences in economic development by the bilateral trade and FDI intensity, government deficit differentials, income disparities and a set of exogenous variables containing institutional differences (POL, ROL, CORRUPT).

\section{Data and variables definition}

We use national level macroeconomic data from various sources, among them, Eurostat, Ameco database, IMF, WDI and national central banks over the period 1995-2012. All variables are bilateral and are constructed as five year rolling windows for the following groups: EU27, EU15, EU15-newEU12, EA11 and Core Vs Periphery. The detailed definition and sources of variables, descriptive statistics and the country groupings used in this study are given in Tables 1, 2 and 3 , respectively.

$$
\begin{aligned}
& \text { [Insert Table } 1 \text { here] } \\
& \text { [Insert Table } 2 \text { here] } \\
& \text { [Insert Table } 3 \text { here] }
\end{aligned}
$$

Financial linkages between two partners are represented as the sum of bilateral assets (FDI stocks) related to the sum of GDP of the two countries, a measure also applied in Fidrmuc et al. (2010) and García-Herrero and Ruiz (2008). FDI was the most challenging variable because of the necessity to work with bilateral FDI stocks. We used in general data on FDI outward stocks. 
Since the data has missing data points due to confidentiality requirements, we had to interpolate and extrapolate the data starting from the trend observed in the series and extending according to the structure of higher level aggregates.

Among the various measures for bilateral trade linkages proposed in the literature we employ bilateral trade flows related to the sum of the partners' GDP, as in Frankel and Rose (1998), Fidrmuc (2004) and Siedschlag (2010), which we find more convincing than the measure relating bilateral trade of the partners to total worldwide trade of both partners as suggested in Imbs (2004) and Fidrmuc et al. (2010). Having the GDP sum in the denominator establishes a relationship with the size of the economies, while this would not necessarily hold when the measure of bilateral trade is related to the total trade volume.

For specialization, as in Imbs (2004) or Siedschlag and Tondl (2011), we use an indicator proposed by Krugman (1991). Our specialization index focuses on specialization in manufacturing based on 23 manufacturing industrial branches. Since we regard trade in goods it seems logical to base the indicator for specialization on manufacturing and not other branches. ${ }^{5}$

\section{$5 \quad$ Empirical facts}

Before turning our attention to the estimation results, we discuss the evolution of the main variables in the different country groupings, namely, EU27, EU15, EU15-newEU12, EA11 and Core Vs Periphery, in Figures 1 - 7.

Figure 1 shows the development of correlations in cyclical components of real GDP. Evidently, correlations are the highest in the EA11 group, followed by EU15 and Core Vs Periphery, while the lowest correlations are observed in the EU15-newEU12 and EU27 groups. Business cycle correlations reached unprecedented levels across all groups during the global financial and economic crisis of 2007-2009, with EA11 even reaching a correlation of almost 0.6 in 2006-2010. Overtime, business cycle correlations reveal a positive trend with a couple of declines in 20002004 and in 2007-2011. The decline of correlations in the 2000-2004 and 2007-2011 appears as a distinct feature with all countries. A look at the data shows that, growth after the 2001-2002 stagnation accelerated with a different timing, stagnated in some countries altogether and saw a second interim stagnation in a few of them. This explains the drop in business cycle correlations in the observation 2000-2004. Another interesting feature is the decoupling of correlations between EA11, Core Vs Periphery and EU15, and EU27 and EU15-newEU12 in 2008-2012 due to the European Debt crisis that affected mostly the peripheral Eurozone countries. Finally, the increase of business cycle synchronization in the EU27 from virtually nothing in 1995-1999 to around 0.3 is particularly noteworthy. Overall, business cycle synchronization increased since the introduction of the euro across all groups in the EU.

[Insert Figure 1 here]

Figure 2 shows that bilateral trade intensity (bilateral trade as share of both countries' GDP) is twice and thrice as high in the EU15 and EA11, respectively, than that in the EU27, and trade intensity between EU15-newEU12 partners are only one fifth of that in the EU15. Trade intensity shows a constant upward trend in all subgroups with similar growth rates, with the exception of the Core Vs Periphery, EU15 and EA11 since 2005-2009 where these groups experienced a decline of trade intensity.

\footnotetext{
${ }^{5}$ Other authors regard specialization with respect to all economic sectors, e.g. Siedschlag (2010) considers 6 sectors of the whole economy, Clark and van Wincoop (2001) uses an indicator with 8 non-manufacturing and 8 manufacturing industries.
} 
Figure 3 shows that bilateral FDI linkages (bilateral FDI stocks as a share of both countries' GDP) have rapidly increased across all groups in the period of concern. The increase was more pronounced in the EA11, EU15 and the Core vs Periphery groups than that in the EU27 and EU15-newEU12. Once again, FDI linkages are stronger among the EA11, EU15 and Core vs Periphery countries, being more than 5 times higher in the EU15 member states than those in the EU15-newEU12 members.

\section{[Insert Figure 3 here]}

Consequently, we see that, in total, EU27 bilateral trade and FDI linkages vary to a considerable extent, comprising country pairs with intensive and very weak linkages.

Figure 4 illustrates the differential in government deficits in absolute terms, our indicator of dissimilarity of fiscal policies. A high differential indicates poor fiscal policy conditions and substantial differences in compliance with the SGP. The evolution of these series is rather idiosyncratic across country groups. In particular, differences in budget deficits have increased throughout the period in the Core Vs Periphery, EU15 and EA11, with a short period of stability between 1997-2001 and 1999-2003, i.e., the introductory stage of the Euro. The increase in budget deficit differences in the Core Vs Periphery are the most pronounced, reaching a peaking in 2008-2012 of around 6.5\%. In contrast, differences in budget deficits have increased between country pairs of EU15-newEU12 and EU27 until 1997-2001, and have been followed by a declining trend, reaching a minimum during during 2003-2007. After that, budget deficit differences for these groups have increased and seem to have been stabilized by the end of our sample. Finally, the only period where differences in the budget deficits were almost identical across all groups of countries, was during the 2002-2006 period with a value of around $3 \%$.

[Insert Figure 4 here]

According to Figure 5, exchange rate volatility has followed a declining trend in the EU until 2003-2007, which was reversed afterwards. The only exception is in the case of the Core Vs Periphery and EA11 countries, wherein exchange rate volatility was eliminated with the introduction of the common currency. Interestingly, exchange rate volatility is three times higher in the EU15-newEU12 countries than that in the EU15 over the period 1995-1999, but only around two times higher since the 2000-2004.

\section{[Insert Figure 5 here]}

Based on Figure 6, manufacturing specialization has seen interesting changes in the EU overtime. Manufacturing specialization has declined in the early part of our sample across all groups, and increased sharply, after a period of stability, in the recent period. This indicates an important structural change across the EU. First the old specialization was dissolved, then countries have specialized in new productions. ${ }^{6}$

\section{[Insert Figure 6 here]}

\footnotetext{
${ }^{6}$ As an alternative measure, we have employed a specialization indicator with 6 industries including both manufacturing and non-manufacturing industries based on data collected from Eurostat. Based on that indicator, specialization is generally less pronounced.
} 
Finally, Figure 7 illustrates the differences in per capita income. Income differences in the EU15-newEU12 and the EU27 have declined in the period of concern, whereas there was a slight increase in the remaining groups. ${ }^{7}$

$$
\text { [Insert Figure } 7 \text { here] }
$$

\section{Results}

Table 4 presents the estimation results for the EU27 as a whole, EU15, and EU15-newEU12, while Table 5 for the EA11 and Core Vs Periphery.

$$
\begin{aligned}
& \text { [Insert Table } 4 \text { here] } \\
& \text { [Insert Table } 5 \text { here] }
\end{aligned}
$$

We find a positive and significant effect of trade and specialization on business cycle synchronization, with the former effect being the most important one throughout the EU. In particular, the effect of trade on BCS is more pronounced within the Eurozone (Core Vs Periphery and EA11) than that within the EU15-newEU12, EU15 or even the EU27 as a whole.

The impact of trade linkages on business cycle synchronization confirms the results found in the literature for the EU15 (e.g. Clark and van Wincoop 2001; Siedschlag and Tondl 2011; Rana et al. 2012), EA12 (e.g. Gouveia and Correia 2013), EU25 (Crespo-Cuaresma et al. 2011), OECD countries (e.g. Fidrmuc 2004) and worldwide samples (e.g. Imbs 2004; Calderón 2003). Here we provide additional evidence for the EU and particularly for the Euro area. ${ }^{8}$

The equation on TRADE reveals that economies with more synchronized business cycles and intensive FDI linkages trade more with each other. The estimation results show that FDI has a high trade enhancing effect in the EU, particularly between the EU15-newEU12, while it is disproportionately low in the Core Vs Periphery. This indicates that vertical FDI (outsourcing) is particularly important between EU15-newEU12 countries, but that market seeking FDI prevails in Core Vs Periphery. In each group, several interesting trade patterns appear. Trade is clearly focusing on countries with equal income levels (negative coefficient on $D G D P P C$ ) and equal regulatory frameworks; only in the group of EU15-newEU12 trade arises between countries with higher income gaps. Furthermore, specialization - which emerges in all samples between equally developed countries (positive coefficient on $S G D P P C$ in $S P E C$ equation) - contributes to the intensive trade linkages between high income countries. Finally, we see that exchange rate volatility discourages trade significantly between EU15-newEU12. ${ }^{9}$

In our system of simultaneous equations we can observe the indirect effects of the channels and determinants of BCS. With respect to trade, we see that it affects FDI, specialization and income disparities (see equations FDI, SPEC and DGDPPC in Tables 4 and 5). Thus, we find indirect effects of trade via FDI, specialization and income disparities. Trade increases specialization in practically all samples, and thus re-enforces the positive effect of specialization on BCS across almost all groups. On the one hand, trade leads to a reduction of income disparities in the EU27 and the Euro Area, and thus indirectly contributes to BCS. On the other hand, trade enhances income disparities in the EU15-newEU12, while no significant effects of trade on income disparities in the EU15 could be identified.

\footnotetext{
${ }^{7}$ Note that this picture remains very similar with the use of GDP per capita in PPP as the basis of construction of the indicator.

${ }^{8}$ This also explains that, in the recent economic crisis, the Euro area members and in particular the peripheral ones suffered immediately from declining export demand and synchronous output decline.

${ }^{9}$ The result corresponds to Frankel and Rose (1998), who suggest that decreasing exchange rate volatility encourages trade, and argue that this is indicative of the endogeneity between trade and currency areas.
} 
The positive coefficient of sectoral specialization is opposite to the findings elsewhere in the literature, e.g. Imbs (2004) and Siedschlag (2010), who find a negative relationship, and Clark and van Wincoop (2001), who find no significant relationship. One explanation for this could be the difference in the specialization indicator employed. Our indicator is based on 23 manufacturing branches whereas the other studies use a sectoral decomposition at a higher aggregation level. ${ }^{10}$ Thus despite specialization, the dominant products produced in the two specialized countries may be complementary so that specialization does not imply specific demand shocks. Another explanation is that our investigation covers more recent data than those in the above studies. ${ }^{11}$ Our indicator of specialization indicates increasing manufacturing specialization in the most recent years of our sample (see Section 5). Nevertheless the size of the direct positive effect of specialization on BCS is much smaller than that of trade. The positive effect of specialization on BCS is more pronounced in the EU27, EU15 and in the EA11 than that in the Core Vs Periphery, while no significant effect of specialization on BCS in the EU15-newEU12 could be identified.

The equation on SPEC provides information on the determinants of specialization in the EU. Most pronounced is the effect of FDI linkages on specialization. We find a positive effect of FDI on specialization in practically all samples, except in the Core Vs Periphery. Thus FDI mostly leads to restructuring and development of comparative advantages to a larger extent than trade does. In particular, in the EU15-newEU12, FDI is a strong driver of increasing specialization. Specialization emerges between equally developed countries (positive coefficient of $S G D P P C$ ) in practically all samples, but also between countries with institutional disparities (positive coefficient of $A C C$ ). The later result corresponds to the findings of Imbs (2004) among others. Our finding suggests that new patterns of specialization have appeared.

We find that specialization also has indirect effects via FDI, trade (a result which is in line with Siedschlag and Tondl, 2011), and exchange rate volatility (see Tables 4 and 5). Specialization triggers FDI (except in the Core Vs Periphery) and thus also results in a negative indirect effect (not significant though in EU15-newEU12) on BCS. Furthermore, since specialization results in almost all samples in increased trade (except for EU15-newEU12) we observe a positive indirect effect of specialization on BCS via trade. Since specialization leads to a need of exchange rate flexibility in EU27 and EU15, it also reduces indirectly BCS. In summary, when we consider both the direct and indirect effects, specialization contributes positively to BCS (see Table 6).

With respect to bilateral FDI linkages, we find across almost all EU groups a negative effect on BCS, - with EU15-newEU12 the coefficient of FDI is not significant (see Tables 4 and 5). This suggests decoupling effects arising from FDI in the EU. If one considers the pure direct effect, then FDI linkages do not lead to enforcing business cycle spillovers between the two partners, rather the oppositve. FDI holdings may thus smoothen demand shocks. The effect is particularly high in the Euro area and the EU15. How can we explain this decoupling effect? Looking at the auxiliary equation that explains bilateral FDI stocks, we observe a significantly negative coefficient of business cycle correlations in explaining FDI stocks in almost all samples

\footnotetext{
${ }^{10}$ Clark and van Wincoop (2001) use 8 manufacturing sectors and 8 non-manufacturing branches and Siedschlag (2010) uses 6 branches of the total economy for the specialization indicator. As mentioned in section 5, we used also an alternative specialization indicator covering 6 manufacturing and non-manufacturing sectors for robustness checks. In this case we found an insignificant coefficient of specialization. However, the specialization variable based on all sectors of the economy and not only on manufacturing sectors resulted in less clear results in the auxiliary equations and an unsatisfactory fit of the specialization equation.

${ }^{11}$ Clark and van Wincoop (2001) look at the period 1970-1993, Siedschlag (2010) investigates the period 19902003.
} 
(except EU15-newEU12). This indicates that FDI searches destinations which do not exhibit the same growth path; in other words, much of this FDI searches to diversify risk and benefit from differently growing markets. It appears in almost all groups that FDI searches destinations with a different income level (positive coefficient of $D G D P P C$ ) but also similarly developed markets (negative coefficient on wage disparity). Between EU15-newEU12, in contrast, FDI searches only equally developed markets (negative coefficient of $D G D P P C$ and wage gap). Evidently, FDI linkages are higher between countries with strong established trade links, as the positive coefficient of trade suggests.

Furthermore, we find a positive coefficient of specialization on FDI across all samples. This suggests that, in contrast to the market-seeking FDI, risk-diversifying FDI also follows competitive advantages of countries in certain sectors. This type of FDI would represent vertical FDI where a part of the production is transferred to another country. The fact that a part of FDI represents vertical FDI is confirmed by the consistently positive coefficient of FDI in both the $T R A D E$ and $S P E C$ equation. Vertical FDI increases trade flows and enforces specialization the latter result is also found in Imbs (2004). This is particularly pronounced in EU15-newEU12. Thus we find positive indirect effects of FDI on BCS. Attracting intermediary products, FDI serves particularly in the EU periphery to achieve BCS with the EU. Looking at Table 6, we see that the indirect effects of FDI suggest a net positive effect of FDI in EU27, EU15, in EA11, Core vs Periphery, and the most pronounced one in EU15-newEU12.

Several empirical studies found a positive direct impact of FDI on BCS (Jansen and Stokman, 2014; Dées and Zorell, 2012; Hsu et al., 2011; Imbs, 2004). While Jansen and Stokman (2014) looks at a set of 8 advanced OECD countries, Imbs (2004) covers 24 developed and developing countries and Dées and Zorell (2012) 25 EU countries. In contrast, García-Herrero and Ruiz (2008) investigate the BCS of Spain with 109 countries worldwide and find a negative relationship. The studies finding a positive coefficient of FDI cover either older time periods and different samples than our study (Imbs 2004: 1980-2000, Jansen and Stokman 2014: 19822011) or have a simpler econometric specification which does not account for the endogeneity of FDI (Jansen and Stokman, 2014; Dées and Zorell, 2012). Furthermore, none of these studies consider the potentially important indirect effects of FDI via trade, specialization and income disparities simultaneously. Therefore their results are not directly comparable to ours. Since we use a more suitable indicator for FDI linkages, account for the endogeneity of FDI and consider various potential indirect effects, we think that our results are more robust than those suggested by Dées and Zorell (2012) for EU25. ${ }^{12}$ The only exception is the study (Hsu et al., 2011), who examine the indirect effects of FDI via trade and specialization in a panel of 15 OECD countries and find that FDI promotes BCS. However, the authors do not examine the potential indirect effects via income disparities, as in our study, neither analyse the net effects, nor focusing only on EU countries.

Turning our attention to the differences in governments budget deficits, we find a negative effect across all samples, except for the EU15, where the coefficient is insignificant. The negative effect of disparities in government fiscal policies on BCS is particularly strong in the EU15newEU12. The effect is of similar magnitude within the EU27 and the Eurozone, while between the Core and the Periphery is more pronounced. These results are in line with previous studies that document that, fiscal policy coordination or better fiscal conditions, based on different proxies, generally lead to increased business cycle synchronization in the EU (see, for instance, Clark and van Wincoop, 2001; Darvas et al., 2005; Camacho et al., 2006; Artis et al., 2008;

\footnotetext{
${ }^{12}$ Dées and Zorell (2012) use the absolute volume of bilateral FDI stocks without relating it to the GDP of the countries involved, as an indication for financial linkages. Since the same volume of FDI can represent either strong FDI linkages existing between small economies, or weak FDI linkages between large economies, this measure is distorted.
} 
Furceri, 2009; Crespo-Cuaresma et al., 2011; Hauge and Skulevold, 2012). Thus there is strong evidence that the initially recorded declining deficit disparities prior to the global economic crisis have fostered BCS, while the increasing deficit disparities in the course of the economic crisis weakened BCS.

The auxiliary equation $G O V D E F$ reveals interesting factors that determine differences in fiscal policies. First, the partly negative coefficient of $C O R R Y$ suggests that differences in fiscal policies are caused by divergent business cycles, and are therefore a consequence of revenue shortfalls or active fiscal adjustment policies. Second, it appears throughout, that differences in government deficits are related to income disparities and dissimilarities in government efficiency. Evidently the different economic and institutional development is an important reason of the mounting disparities in government deficits. Third, the positive coefficient of LINT in the EU15 and the Eurozone shows that, also rising interest disparities are responsible for mounting disparities in budgetary deficits. Note that the coefficient of LINT is negative in the EU15newEU12 and EU27 as a whole. Here, budgetary disparities have developed despite falling interest rate differentials. Government deficit disparities not only reduce directly BCS, but also indirectly, via increased exchange rate volatility in the EU27. The effect is less clear in the EU15 and EU15-newEU12. Equally important is the indirect negative impact of budget deficits on BCS via income disparities. Higher deficits lead to an increase in income disparities in all groups (see equation $D G D P P C$ ), and thus indirectly BCS is reduced in the EU27 and EU15newEU12. The net effect of disparities in government deficits remains negative in the EU27 and EU15-newEU12, however, it becomes positive in the Eurozone as the slight increase in income disparities in the Eurozone does not hinder BCS (see Table 6).

Overall, the results that diverging fiscal policies have discouraged BCS are in line with Darvas et al. (2005), who finds that fiscal convergence lead to more synchronized business cycles in 21 OECD countries over the period 1963-2003. In contrast, we cannot confirm the results of Clark and van Wincoop (2001), who do not find any significant effect of differences in fiscal policy on BCS in the EU15 between 1981 and 1997.

Exchange rate volatility is an important negative factor impeding BCS particularly in the EU15 and also in the EU27 as a whole, which is in line with Siedschlag and Tondl (2011). This does, however, not appear in the EU15-newEU12, where the coefficient is insignificant. These results suggest that, exchange rate alignments within the latter group may serve as an adjustment instrument. As long as such adjustment via exchange rate flexibility is required by an EU member, it will not discourage BCS and should be maintained. Whether joining the Euro thus needs prudent reflection. Since exchange rate volatility can by definition not occur in the EMU, this factor was obviously not included in the estimations with the Eurozone samples. In the auxiliary equation on $E X C H$ we find that the need for exchange rate volatility arises in all groups: EU15, EU15-newEU12, and EU27 as a consequence of poor BCS. Exchange rate volatility is always observed with high specialization between country pairs, suggesting that flexible exchange rates are used to adjust for sector-specific shocks. Furthermore, exchange rate volatility is always caused by inflation differentials. In the EU15 and EU27, we also find that volatility corresponds to interest differentials. Moreover, it corresponds to high income disparities and government deficit differences in the EU15-newEU12 and EU27 as a whole. In contrast, exchange rate volatility is observed with countries showing small income differences in the EU15, suggesting that exchange rates are used to a large extent to counteract poor BCS and sector-specific shocks. Since the $E X C H$ equation still showed a poor fit, despite this variety of factors in the sample of EU15-newEU12, we extended the specification of $E X C H$ and found that, differentials in domestic credit activity can very well explain exchange rate volatility in this group. Mounting credit lending in the newEU12 has resulted in more exchange rate volatility. Although there is no statistically significant direct negative effect of exchange rate volatility on 
BCS in the EU15-newEU12, we find an indirect negative effect via trade in EU15-newEU12 (see Table 6).

Moreover, our estimates reveal a statistically significant negative effect of income differences on BCS in the EU15-newEU12 and EU27 as a whole, which is in line with the few findings in the literature on the effects of income levels on BCS (e.g. Louis and Tozman, 2010). Thus the decline of income disparities in these groups helped to synchronize business cycles. In contrast, the slightly increasing income disparities in the EA11 and Core vs Periphery did not harm BCS. We find that income differences produce several indirect effects on BCS (see Table 6): via FDI and trade which are encouraged or discouraged by income differences, government deficits and exchange rate volatility. In summary, income differences produce a net negative effect on BCS across all samples.

The auxiliary equation explaining income disparities $(D G D P P C)$ reveals further interesting regularities. In particular, we find a negative relationship with disparities in government deficits and institutions - be it rule of law, corruption or political stability - across all samples. Thus institutional upgrading and strict coordination of budgetary policies seems to be a prerequisite so as to decrease income disparities in the EU. In addition, we find that poor trade relations characterize countries with income disparities in the Eurozone and the EU27. In the EU15newEU12, in contrast, countries with poor FDI relations show high income disparities.

If we consider both the direct and indirect effects of our variables on BCS together, i.e., the net effects reported in Table 6, we can conclude that trade and specialization lead to more business cycle synchronization in the EU, while differences in income and exchange rate volatility, have decoupling compound effects on business cycle synchronization across the EU. ${ }^{13}$ Interestingly, the net effect of FDI on BCS is positive and robust across all EU groups, and in general, of equal or even greater importance than that of trade. This result suggest a call for additional research that takes into account FDI into the macroeconomic modeling of BCS in the EU, as also suggested by Hsu et al. (2011). Last but not least, the net effects of government deficit disparities on BCS is negative in the EU as a whole, in the EU15 and EU15-newEU12, due to dominance of the direct effects of fiscal disparities on BCS, while in the Eurozone, the net effect of fiscal divergencies on BCS is positive, because of the dominance of the indirect effect of GOVDEF via income differences over the direct effect of fiscal divergencies on BCS. The latter results is plausible, as the countries who suffered the most pronounced reduction in their standards of living from austerity measures implemented in the recent years, are the beleaguered southern Eurozone countries. For instance, GDP per capita declined cumulatively by $22 \%$ in Greece between 2008 and 2012, while in Germany it increased cumulatively by $4.4 \%$ during the same period, according to data from the AMECO database, thereby intensifying income disparities between strong and weaker Eurozone members.

\section{Conclusions}

Business Cycle Synchronization (BCS) is an important prerequisite and objective for the smooth functioning of the common monetary policy in the Eurozone. The aim of this study is to examine whether market integration policies and common or coordinated economic policies can improve business cycle synchronization. To achieve that, we employ a system of simultaneous equations and take into account additional indirect channels and factors that could potentially affect business cycle synchronization, that were largely overlooked in the existing literature.

Thus, the contribution of our study is twofold. First, we examine the direct, indirect and

\footnotetext{
${ }^{13}$ The only exception is EA11, wherein we observe a net, albeit small, negative effect of trade on BCS due to the dominance of the negative indirect of trade on BCS via FDI over the direct effect of trade on BCS.
} 
overall effects of integration and coordinated economic policies on BCS, by including determinants in our estimations which have been largely discounted in previous EU studies. Second, we extend the well established simultaneous equations approach used in the literature, and use a more elaborate model with seven factors permitting a multitude of endogenous relations between them. As a result our model achieves a high statistical determination, and we are able to unravel the character of multiple direct and indirect effects more thoroughly.

Based on the evolution of the aforementioned series, we observe that business cycles have become more synchronized in the EU, and especially since the introduction of the common currency. Co-movements are more pronounced in the EA11, EU15 and Core Vs Periphery than those between the EU15 and the newEU12 countries, however, in the latter groups we also observe an increasing trend in business cycle synchronization. Trade integration and FDI linkages have increased strikingly in EU27 in the period of concern. Nevertheless, trade and FDI integration are by far the most advanced in the core of the EU. Differences in government deficits have declined substantially in the EU27, but have increased in the EU15. Exchange rate volatility has also significantly declined. After an early period of de-specialization in the manufacturing sector, we observe a modest but steady increase in manufacturing specialization in the whole EU. Income differences have constantly declined in the EU27 attributable to the catching up in the new member states. In the EU15, income differences have increased slightly.

Turning to our estimation results from the system of simultaneous equations we conclude that trade, FDI and specialization have, in general, a positive effect on the synchronization of business cycles in the EU. We find also clear evidence that exchange rate fluctuations and income disparities inhibit synchronization of business cycles. In addition, diverging government fiscal policies impede business cycle synchronization in general. Due to its trade enhancing effect, FDI has a positive net effect on business cycle synchronization across all EU samples.

Since our results show that intra-EU trade concentrates largely on equally developed members, and that more trade reduces income disparities, less developed EU countries need to watch the development of trade linkages if they wish to be suitable EMU members. The results also suggest that weaker EU members can develop their trade relations if they host intermediary product FDI. This type of FDI serves the periphery to achieve BCS.

Unlike most of the literature, we find that increasing manufacturing specialization does not harm BCS, rather the opposite is true. We observe that specialization in the EU27 and in the Euro Area has recently increased sharply between equally developed countries, promoting trade. This type of specialization leads to complementary productions and is compatible with more correlated business cycles. The importance of specialization as business cycle determinant is nevertheless minor compared to other factors.

The coordination of monetary policies and the introduction of the Euro have to be considered as an important source for BCS in the EU and in particular in the EU15. However, in the case of the EU15-newEU12 country pairs this does not necessarily apply. Here exchange rate flexibility between new and incumbent EU members has to be considered as a necessary adjustment mechanism to stabilize diverging growth. In our system of simultaneous equations model we can also explain the source of exchange rate volatility, namely, poor synchronization of business cycles, sector-specific effects, differentials in inflation rates and government deficits. In these cases, exchange rate flexibility is required. Since this is strong evidence that, under poor business cycle synchronization, a common exchange rate policy is not feasible, EU countries with these characteristics should not be seriously considered as close EMU candidates. The results also suggest that Euro members with substantial deficits and inflation differentials will see an increasing pressure for individual exchange rate policy.

The decline in differences in budgetary deficits in the EU27 has promoted business cycle convergence. EU countries with substantially different fiscal policies can achieve BCS and thus 
qualify for EMU membership through compliance with the deficit convergence criteria. This advocates a regime of stringent fiscal policy coordination to guarantee the degree of BCS sufficient for the smooth operation of a common monetary policy. The results obtained in our system of simultaneous equations further show that, differences in public deficits in the EU are linked to differences in income and government efficiency. Thus particularly poorer EU members have to be supported to improve budgetary processes and efficiency of government operations.

Finally, we find clear evidence that income convergence has promoted business cycle convergence in the EU27. Thus the EU has to face the fact that big income differences among its members are not compatible with a monetary union. Income convergence in turn has benefitted from trade integration policy. In contrast, mounting disparities in government deficits and austerity policies endanger income convergence.

In summary, some major policy implication arise from this study. First, the EU needs to broaden the entry/convergence criteria to EMU. Second, beyond the present indicators, also the extent of trade and FDI linkages, sectoral specialization, institutional differences and income differences in general need to be considered. Third, compliance with these criteria needs to be supervised permanently and not only in the pre-entry stage in order to guarantee business cycle synchronization in the Eurozone that is essential for a viable Euro. Forth, the EU has to strictly enforce the SGP, but at the same time needs to develop fiscal policy instruments which can provide adjustment to individual EMU members. Ironically such points were already made in the planning stage of the Euro. ${ }^{14}$

\section{Acknowledgements}

Research for this study has been undertaken as part of the project "The Impact of the Single Market on Cohesion" commissioned by the European Commission, DG Regio. The authors would like to thank Iain Begg, colleagues from the European Commission and participants at the Johannes Kepler University's Departmental Seminar for helpful suggestions, and the Editor of Empirica, Fritz Breuss, and two anonymous reviewers for their insightful comments on a previous draft of this paper.

\section{References}

Akin, C., 2012. Multiple Determinants of Business Cycle Synchronization. Tech. rep., SSRN. URL http://dx.doi.org/10.2139/ssrn.1022648

Artis, M. J., Fidrmuc, J., Scharler, J., 2008. The Transmission of Business Cycles Implications for EMU Enlargement. Economics of Transition 16, 559-682.

Artis, M. J., Zhang, W., 1997. International Business Cycles and the ERM: Is There a European Business Cycle? International Journal of Finance \& Economics 2 (1), 1-16.

Backus, D. K., Kehoe, P. J., Kydland, F. E., 1992. International Real Business Cycles. Journal of Political Economy 100 (4), 745-75.

Badinger, H., Breuss, F., 2004. What has Determined the Rapid Post-War Growth of Intra-EU Trade? Review of World Economics (Weltwirtschaftliches Archiv) 140 (1), 31-51.

\footnotetext{
${ }^{14}$ See the debate on the Optimum Currency Area which stresses the need for individual adjustment instrument (Mundell, 1961) and the debate for real convergence criteria (e.g. Beine and Hecq, 1998).
} 
Beine, M., Hecq, A., 1998. Codependence and Convergence in the EC Economies. Journal of Policy Modeling 20 (4), 403-426.

Calderón, C., 2003. Do Free Trade Agreements Enhance the Transmission of Shocks Across Countries? Working Papers Central Bank of Chile 213, Central Bank of Chile.

Camacho, M., Perez-Quiros, G., Saiz, L., 2006. Are European Business Cycles Close Enough to be Just One? Journal of Economic Dynamics and Control 30 (9-10), 1687-1706.

Canova, F., Ciccarelli, M., Ortega, E., 2012. Do Institutional Changes Affect Business Cycles? Evidence from Europe. Journal of Economic Dynamics and Control 36 (10), 1520-1533.

Cerqueira, P. A., Martins, R., 2009. Measuring the Determinants of Business Cycle Synchronization Using a Panel Approach. Economics Letters 102 (2), 106-108.

Clark, T. E., van Wincoop, E., 2001. Borders and Business Cycles. Journal of International Economics 55 (1), 59-85.

Crespo-Cuaresma, J., Pfaffermayr, M., Amador, O. F., Keppel, C., Mar. 2011. Macroeconomic Aspects of European Integration: Fiscal Policy, Trade Integration and the European Business Cycle. FIW Research Reports series III-004, FIW.

Darvas, Z., Rose, A. K., Szapry, G., 2005. Fiscal Divergence and Business Cycle Synchronization: Irresponsibility is Idiosyncratic. NBER Working Papers 11580, National Bureau of Economic Research, Inc.

Dées, S., Zorell, N., 2012. Business Cycle Synchronisation: Disentangling Trade and Financial Linkages. Open Economies Review 23 (4), 623-643.

Devereux, M. B., Yetman, J., 2010. Leverage Constraints and the International Transmission of Shocks. Journal of Money, Credit and Banking 42 (s1), 71-105.

Fidrmuc, J., 2004. The Endogeneity of the Optimum Currency Area Criteria, Intra-industry Trade, and EMU Enlargement. Contemporary Economic Policy 22 (1), 1-12.

Fidrmuc, J., Iwatsubo, K., Ikeda, T., 2010. Financial Integration and International Transmission of Business Cycles: Evidence from Dynamic Correlations. Discussion Papers 1007, Graduate School of Economics, Kobe University.

Fontagné, L., Freudenberg, M., 1999. Endogenous Symmetry of Shocks in a Monetary Union. Open Economies Review 10 (3), 263-287.

Fontagné, L., Freudenberg, M., Péridy, N., 1998. Intra-Industry Trade and the Single Market: Quality Matters. CEPR discussion papers.

Frankel, J. A., Rose, A. K., 1998. The Endogeneity of the Optimum Currency Area Criteria. Economic Journal 108 (449), 1009-25.

Furceri, D., 08 2009. Fiscal Convergence, Business Cycle Volatility, and Growth. Review of International Economics 17 (3), 615-630.

García-Herrero, A., Ruiz, J. M., 2008. Do Trade and Financial Linkages Foster Business Cycle Synchronization in a Small Economy? Moneda y Credito 226 (1), 187-226. 
Gouveia, S., Correia, L., 2013. Trade Integration and Business Cycle Synchronization in the Euro Area: The Case of Southern European Countries. Journal of Economic Integration 28, $85-107$.

Hauge, J. P., Skulevold, P.-S. V., 2012. Fiscal Policy Convergence and Business Cycle Synchronization in the Euro Area. MSc thesis, BI Norwegian Business School.

Hsu, C.-C., Wu, J.-Y., Yau, R., 2011. Foreign Direct Investment and Business Cycle Comovements: The Panel Data Evidence. Journal of Macroeconomics 33 (4), 770-783.

Imbs, J., 2004. Trade, Finance, Specialization, and Synchronization. The Review of Economics and Statistics 86 (3), 723-734.

Imbs, J., 2006. The Real Effects of Financial Integration. Journal of International Economics 68 (2), 296-324.

Inklaar, R., Jong-A-Pin, R., de Haan, J., 2008. Trade and Business Cycle Synchronization in OECD Countries: A Re-examination. European Economic Review 52 (4), 646-666.

Jansen, J. W., Stokman, A. C. J., 2014. International Business Cycle Co-movement: the Role of FDI. Applied Economics 46, 383-393.

Jones, J., Witte, M., 2011. Financial Integration and Business Cycle Synchronization in the Expanded EU. Atlantic Economic Journal 39 (1), 99-100.

Kalemli-Ozcan, S., Papaioannou, E., 2009. Financial Integration and Business Cycle Synchronization. NBER Working Paper Series 14887, National Bureau of Economic Research.

Kalemli-Ozcan, S., Papaioannou, E., Peydr, J.-L., 2013. Financial Regulation, Financial Globalization, and the Synchronization of Economic Activity. Journal of Finance 68 (3), 1179-1228.

Kalemli-Ozcan, S., Sørensen, B. E., Yosha, O., 2003. Risk Sharing and Industrial Specialization: Regional and International Evidence. American Economic Review 93 (3), 903-918.

Kenen, P., 1969. The Theory of Optimum Currency Areas: An Eclectic View, in R. Mundell and A. Swoboda eds, Monetary Problems of the International Economy. The University of Chicago Press, Chicago.

Kose, M. A., Prasad, E. S., Terrones, M. E., 2003. How Does Globalization Affect the Synchronization of Business Cycles? American Economic Review 93 (2), 57-62.

Kröger, J., Kuhnert, S., McCarthy, M., 2010. Contagion and Spillovers: New Insights from the Crisis. SUERF The European Money and Finance Forum, Vienna 2010, Ch. 3: Contagion and Spillovers: Recent European Experience, pp. 25-46.

Krugman, P., 1991. Geography and Trade. MIT Press, Cambridge, MA.

Louis, R. J., S. D., Tozman, A., 2010. Business Cycles Synchronicity and Income Levels: Is There a Single World Business Cycle?, presented at the Annual conference of the Canadian Economic Association 2010.

McKinnon, R. I., 1963. Optimum Currency Areas. American Economic Review 53, 717-724.

Mundell, R. A., 1961. A Theory of Optimum Currency Areas. The American Economic Review 51. 
Pelkmans, J., 2006. European Integration: Methods and Economic Analysis. Pearson, Harlow.

Rana, P. B., Cheng, T., Chia, W.-M., 2012. Trade Intensity and Business Cycle Synchronization: East Asia versus Europe. Journal of Asian Economics 23 (6), 701-706.

Rose, A. K., 2000. One Money, One Market: The Effect of Common Currencies on Trade. Economic Policy 15 (30), 7-46.

Siedschlag, I., 2010. Patterns and Determinants of Business Cycle Synchronization in the Enlarged European Economic and Monetary Union. Eastern Journal of European Studies 1, $21-44$.

Siedschlag, I., Tondl, G. ., 2011. Regional Output Growth Synchronisation with the Euro Area. Empirica 2, 203-221.

Wooldridge, J., 2006. Introductory Econometrics. MIT Press, Massachusetts.

Zellner, A., 1962. An Efficient Method of Estimating Seemingly Unrelated Regressions and Tests for Aggregation Bias. Journal of the American Statistical Association 57 (298), 348-368. 


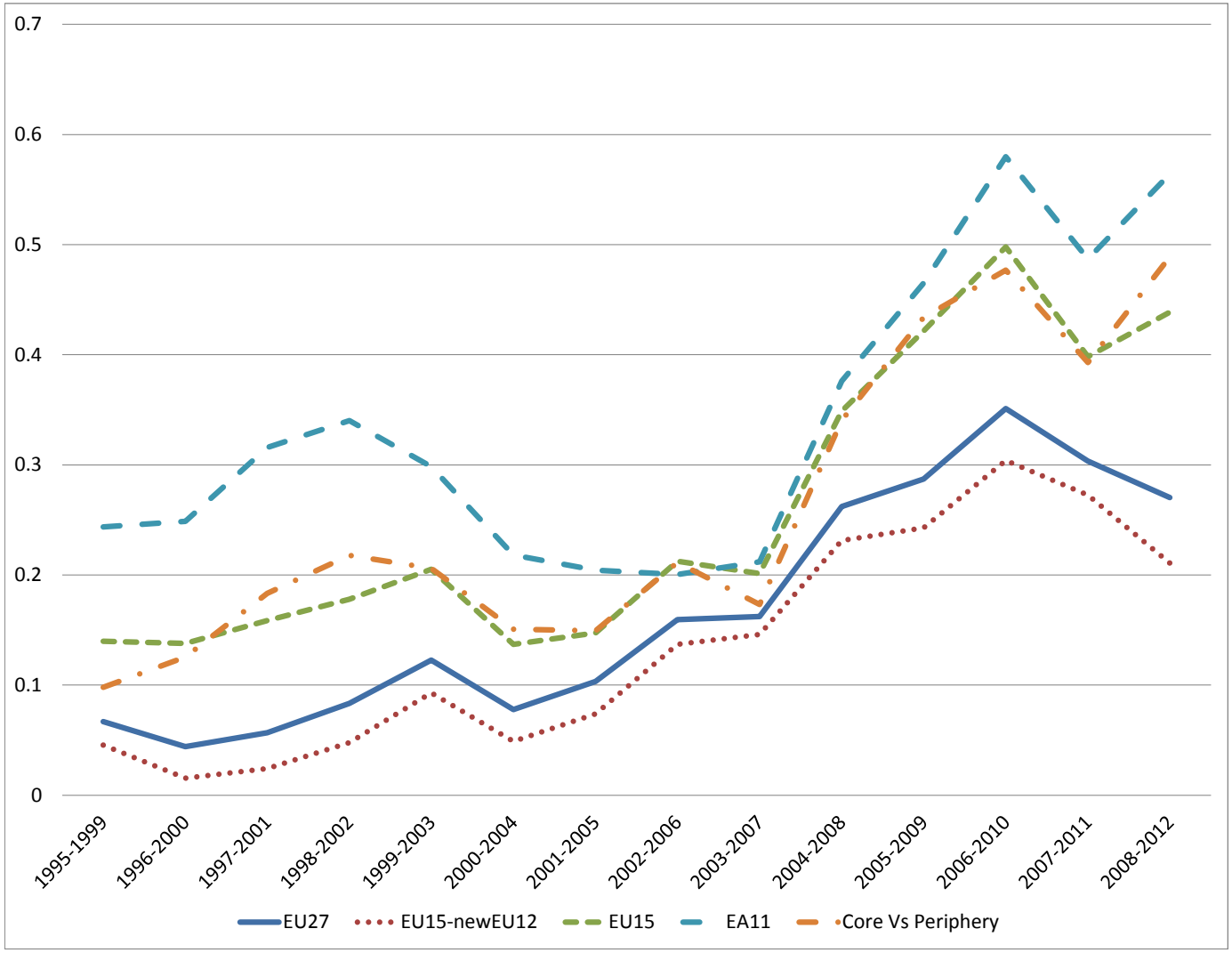

Figure 1: Correlations of HP filtered real GDP (5-year rolling windows, group mean) 


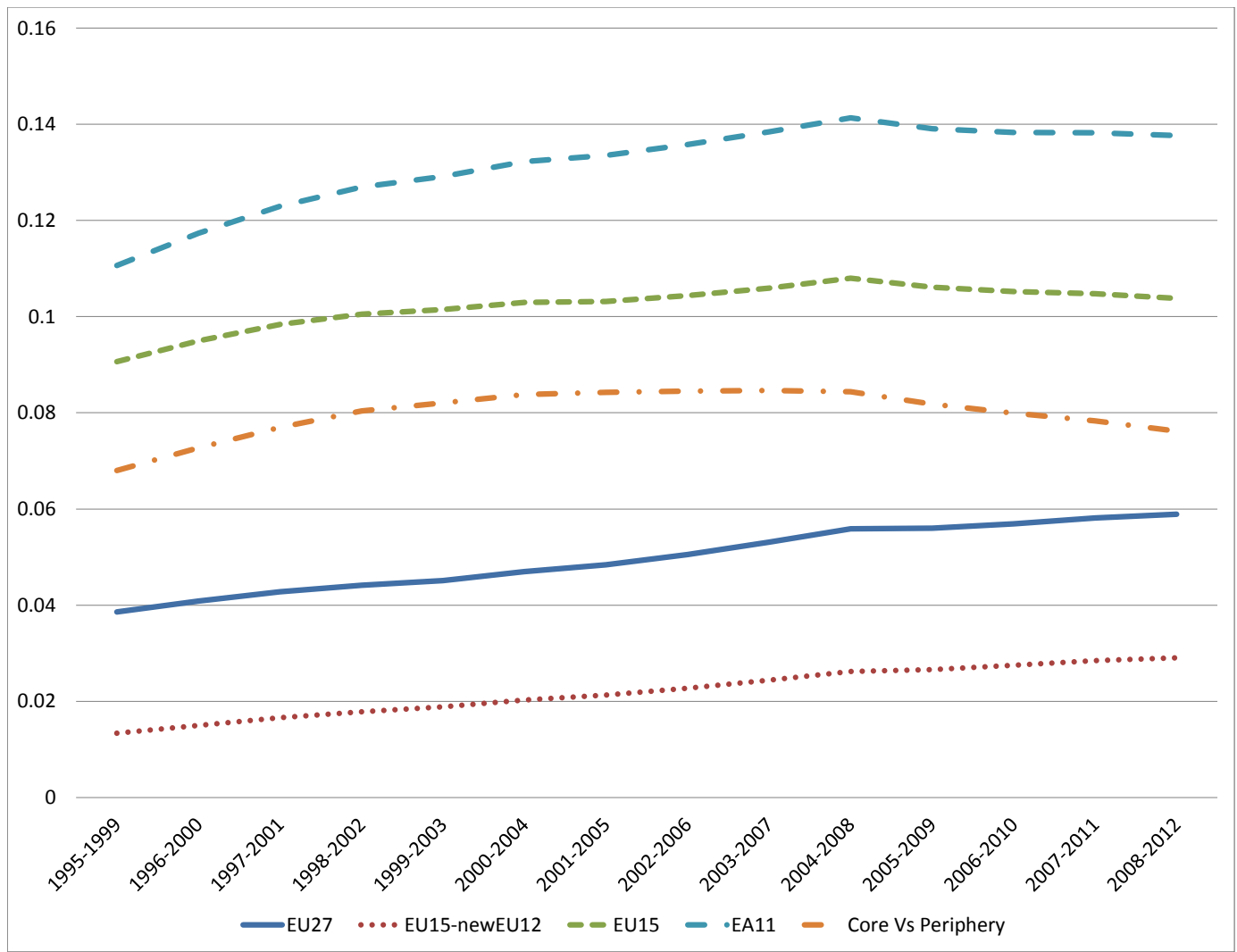

Figure 2: Bilateral trade intensity (5-year rolling windows, group mean) 


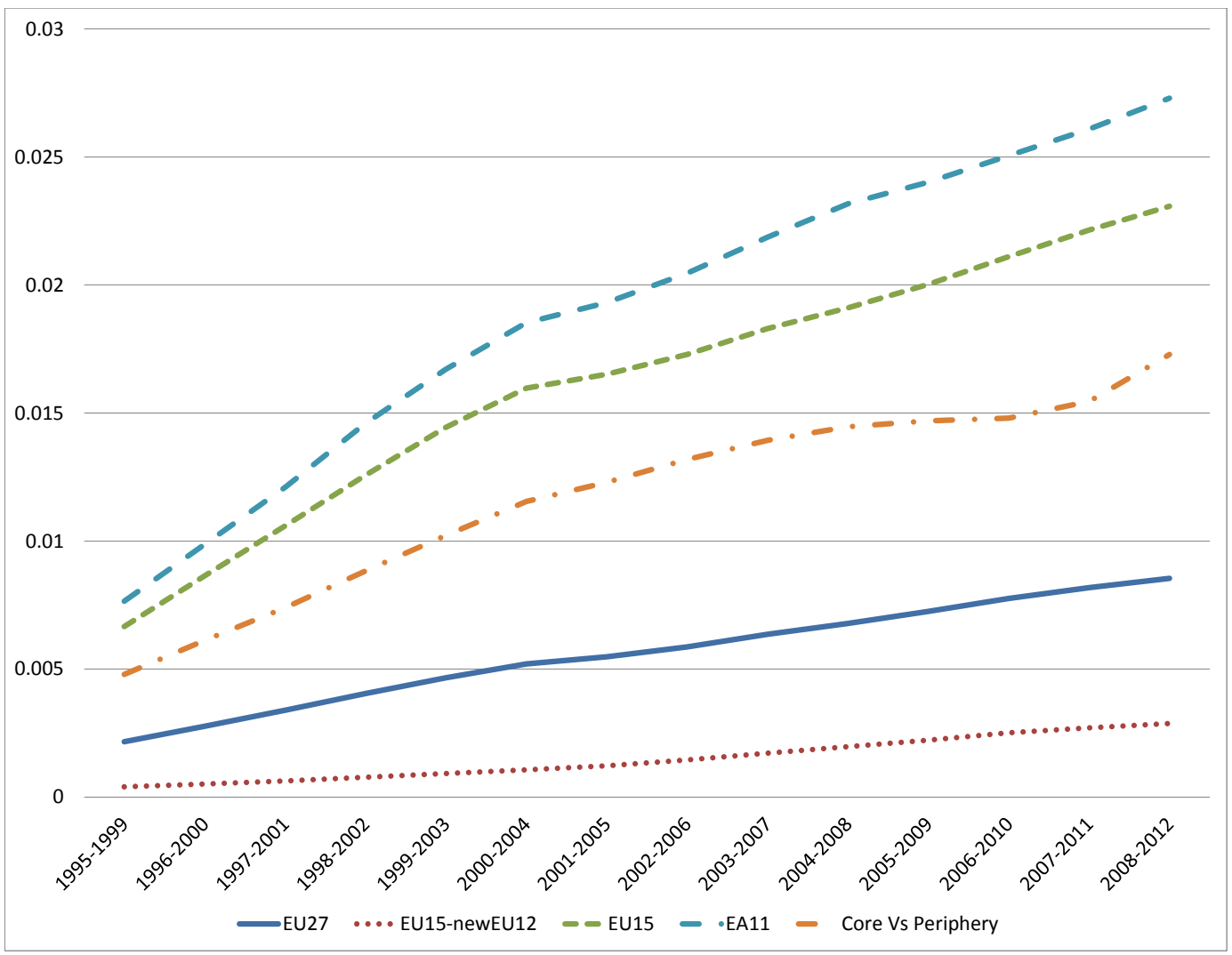

Figure 3: Bilateral FDI intensity (5-year rolling window, group mean) 


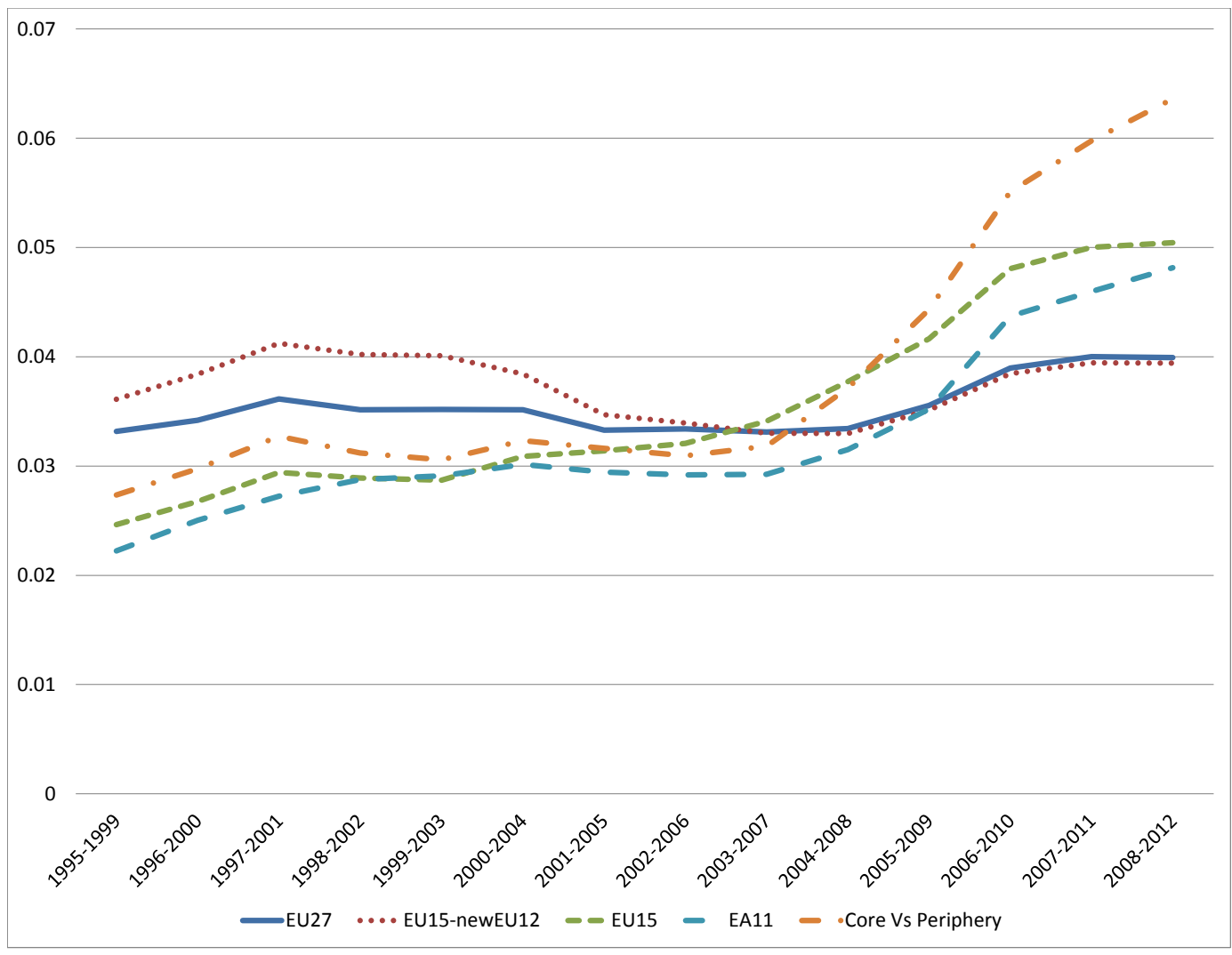

Figure 4: Bilateral differences in government budget balance (5-year averages, group mean) 


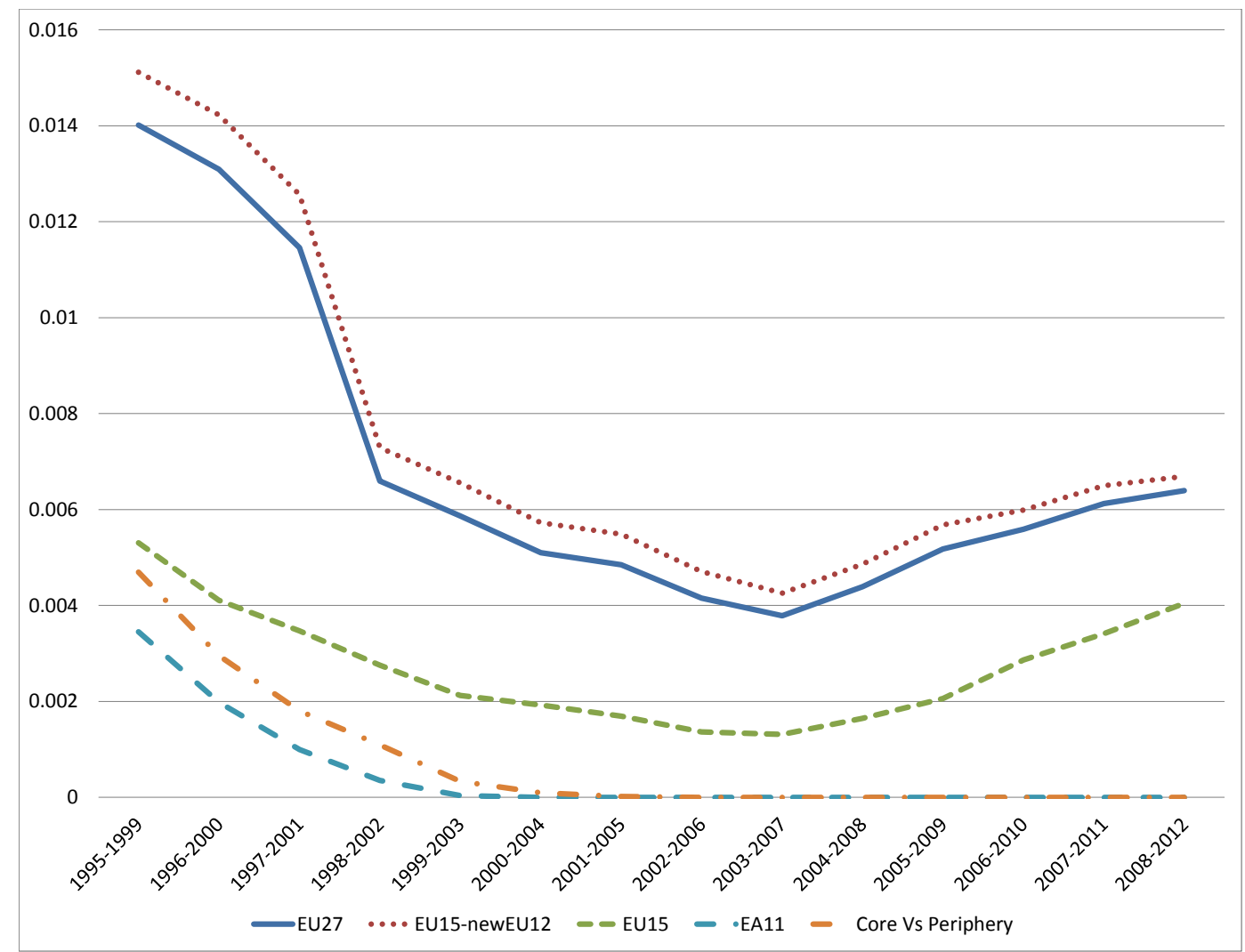

Figure 5: Bilateral exchange rate volatility (5-year rolling window, group mean) 


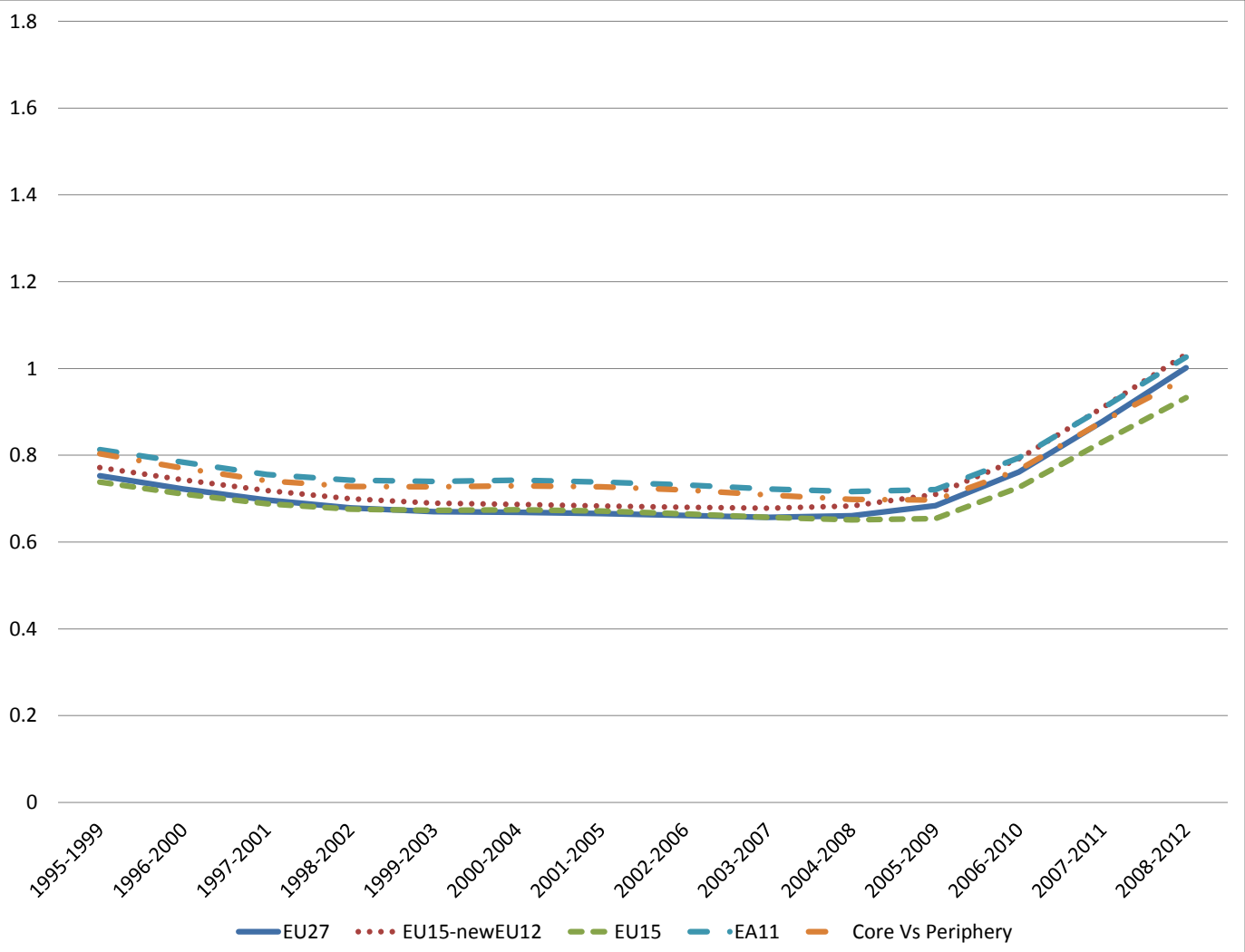

Figure 6: Bilateral sectoral dissimilarity (specialization; 5-year averages, group mean) 


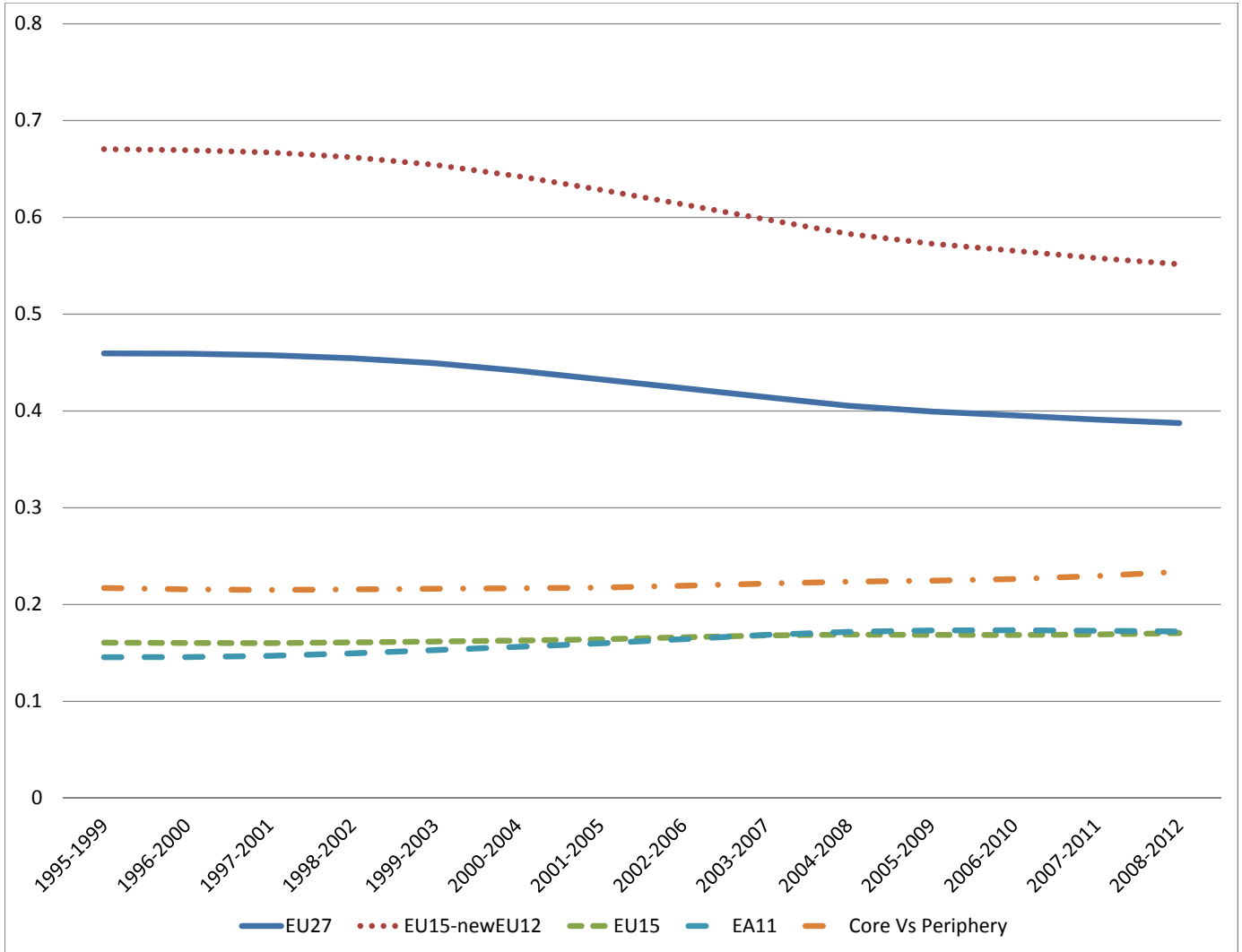

Figure 7: Bilateral per capita income differences (5-year averages, group mean) 
Table 1: Variable definitions and sources

\begin{tabular}{|c|c|c|}
\hline Variable & Definition & Source \\
\hline$C O R R Y_{i j t}$ & $\begin{array}{l}\text { Fisher's z transformation of correlations of annualized quarterly } \\
\text { HP filtered } \log \text { real GDP series between country } i \text { and } j \text { : } \\
C O R R Y_{i j t}=\frac{1}{2} \log \left(\frac{1+C O R R Y_{-} Y_{i j t}}{1-C O R R Y_{-} Y_{i j t}}\right)\end{array}$ & $\begin{array}{l}\text { Authors' calculations } \\
\text { based on EUROSTAT data }\end{array}$ \\
\hline$T R A D E_{i j t}$ & $\begin{array}{l}\text { Sum of exports and imports (in Euros) of country } i \text { to country } j \\
\text { divided by the sum of country's } i \text { and } j \text { GDP (in Euros) at } \\
\text { market prices }\end{array}$ & $\begin{array}{l}\text { Authors' calculations } \\
\text { based on COMEXT, } \\
\text { IMF DOTS and } \\
\text { EUROSTAT data }\end{array}$ \\
\hline$F D I_{i j t}$ & $\begin{array}{l}\text { Sum of outward position from country } i \text { to } j \text { and from country } \\
j \text { to } i \text { divided by the sum of GDP in country } i \text { and } j\end{array}$ & $\begin{array}{l}\text { Authors' calculations } \\
\text { based on EUROSTAT, } \\
\text { UNCTAD, OECD IDIS and } \\
\text { National Bank Statistics data }\end{array}$ \\
\hline$G O V D E F_{i j t}$ & $\begin{array}{l}\text { Absolute difference of budget deficit (as a share of GDP) between } \\
\text { country } i \text { and } j\end{array}$ & $\begin{array}{l}\text { Authors' calculations based } \\
\text { on EUROSTAT and CIA } \\
\text { Factbook data }\end{array}$ \\
\hline$E X C H_{i j t}$ & $\begin{array}{l}\text { Annual standard deviation of quarterly first difference bilateral } \\
\text { log exchange rates between country } i \text { and } j\end{array}$ & $\begin{array}{l}\text { Authors' calculations based } \\
\text { on IMF-IFS data }\end{array}$ \\
\hline$I N F L_{i j t}$ & $\begin{array}{l}\text { Absolute difference of annual average of quarterly inflation rate } \\
\text { between country } i \text { and } j\end{array}$ & $\begin{array}{l}\text { Authors' calculations based } \\
\text { on IMF-IFS data }\end{array}$ \\
\hline$L I N T_{i j t}$ & $\begin{array}{l}\text { Absolute difference of annual average of quarterly differentials } \\
\text { of } 10 \text {-year government bond yields between country } i \text { and } j\end{array}$ & $\begin{array}{l}\text { Authors' calculations based } \\
\text { on IMF-IFS and EUROSTAT } \\
\text { data }\end{array}$ \\
\hline$S I N T_{i j t}$ & $\begin{array}{l}\text { Absolute difference of annual average of quarterly differentials } \\
\text { of money market rate between country } i \text { and } j\end{array}$ & $\begin{array}{l}\text { Authors' calculations based } \\
\text { on IMF-IFS and EUROSTAT } \\
\text { data }\end{array}$ \\
\hline$S P E C_{i j t}$ & $\begin{array}{l}\text { The industrial specialisation index is computed using gross value } \\
\text { added disaggregated on the } 23 \text { branches of the UNIDO industry } \\
\text { sectors (ISIC } 2 \text { digit, Rev.3). The specialisation index for } \\
\text { country } i \text { and } j \text { is defined as follows: } S P E C_{i j t}=\sum_{n=1}^{N}\left|s_{k i t}-s_{k j t}\right| \\
s_{k i t} \text { is the share of sector } k \text { in country } i \text { and } s_{k j t} \text { is the share } \\
\text { of sector } k \text { in country } j \text {. The index ranges from } 0 \text { to } 2 \text {. A value } \\
\text { equal to } 0 \text { indicates complete similarity of industrial structure, } \\
\text { and a value equal } 2 \text { indicates total specialisation. }\end{array}$ & $\begin{array}{l}\text { Authors' calculations based } \\
\text { on UNIDO data }\end{array}$ \\
\hline$W A G E_{i j t}$ & $\begin{array}{l}\text { Absolute difference of log of monthly wage (in current Euros) } \\
\text { between country } i \text { and } j\end{array}$ & $\begin{array}{l}\text { Authors' calculations based } \\
\text { on LABORSTA, UNIDO } \\
\text { and IMF-IFS data }\end{array}$ \\
\hline$S G D P_{i j t}$ & Sum of $\log$ of real GDP (in billion Euros) in country $i$ and $j$ & $\begin{array}{l}\text { Authors' calculations based } \\
\text { on WDI World Bank data }\end{array}$ \\
\hline$D G P D P C_{i j t}$ & $\begin{array}{l}\text { Absolute difference of log of real GDP per capita between country } \\
i \text { and } j\end{array}$ & $\begin{array}{l}\text { Authors' calculations based } \\
\text { on WDI World Bank data }\end{array}$ \\
\hline$D O M C R E D_{i j t}$ & $\begin{array}{l}\text { Absolute difference of domestic credit to private sector } \\
\text { (as a share of GDP) between } i \text { and } j\end{array}$ & $\begin{array}{l}\text { Authors' calculations based } \\
\text { on WDI World Bank data }\end{array}$ \\
\hline$P O L_{i j t}$ & $\begin{array}{l}\text { Political Stability \& Absence of Violence/Terrorism (0-10 index) } \\
\text { differential between country } i \text { and } j \text { in absolute terms }\end{array}$ & $\begin{array}{l}\text { Authors' calculations based } \\
\text { on WGI data }\end{array}$ \\
\hline$A C C_{i j t}$ & $\begin{array}{l}\text { Democratic Accountability ( } 0-10 \text { index) differential between country } \\
i \text { and } j \text { in absolute terms }\end{array}$ & $\begin{array}{l}\text { Authors' calculations based } \\
\text { on WGI data }\end{array}$ \\
\hline$G O V E F F_{i j t}$ & $\begin{array}{l}\text { Government Effectiveness ( } 0 \text {-10 index) differential between country } \\
i \text { and } j \text { in absolute terms }\end{array}$ & $\begin{array}{l}\text { Authors' calculations based } \\
\text { on WGI data }\end{array}$ \\
\hline$R E G_{i j t}$ & $\begin{array}{l}\text { Regulatory Quality ( } 0-10 \text { index) differential between country } \\
i \text { and } j \text { in absolute terms }\end{array}$ & $\begin{array}{l}\text { Authors' calculations based } \\
\text { on WGI data }\end{array}$ \\
\hline$R O L_{i j t}$ & $\begin{array}{l}\text { Rule of Law ( } 0-10 \text { index) differential between country } i \text { and } j \\
\text { in absolute terms }\end{array}$ & $\begin{array}{l}\text { Authors' calculations based } \\
\text { on WGI data }\end{array}$ \\
\hline$C O R R U P T_{i j t}$ & $\begin{array}{l}\text { Control of Corruption ( } 0 \text {-10 index) differential between country } \\
i \text { and } j \text { in absolute terms }\end{array}$ & $\begin{array}{l}\text { Authors' calculations based } \\
\text { on WGI data }\end{array}$ \\
\hline
\end{tabular}




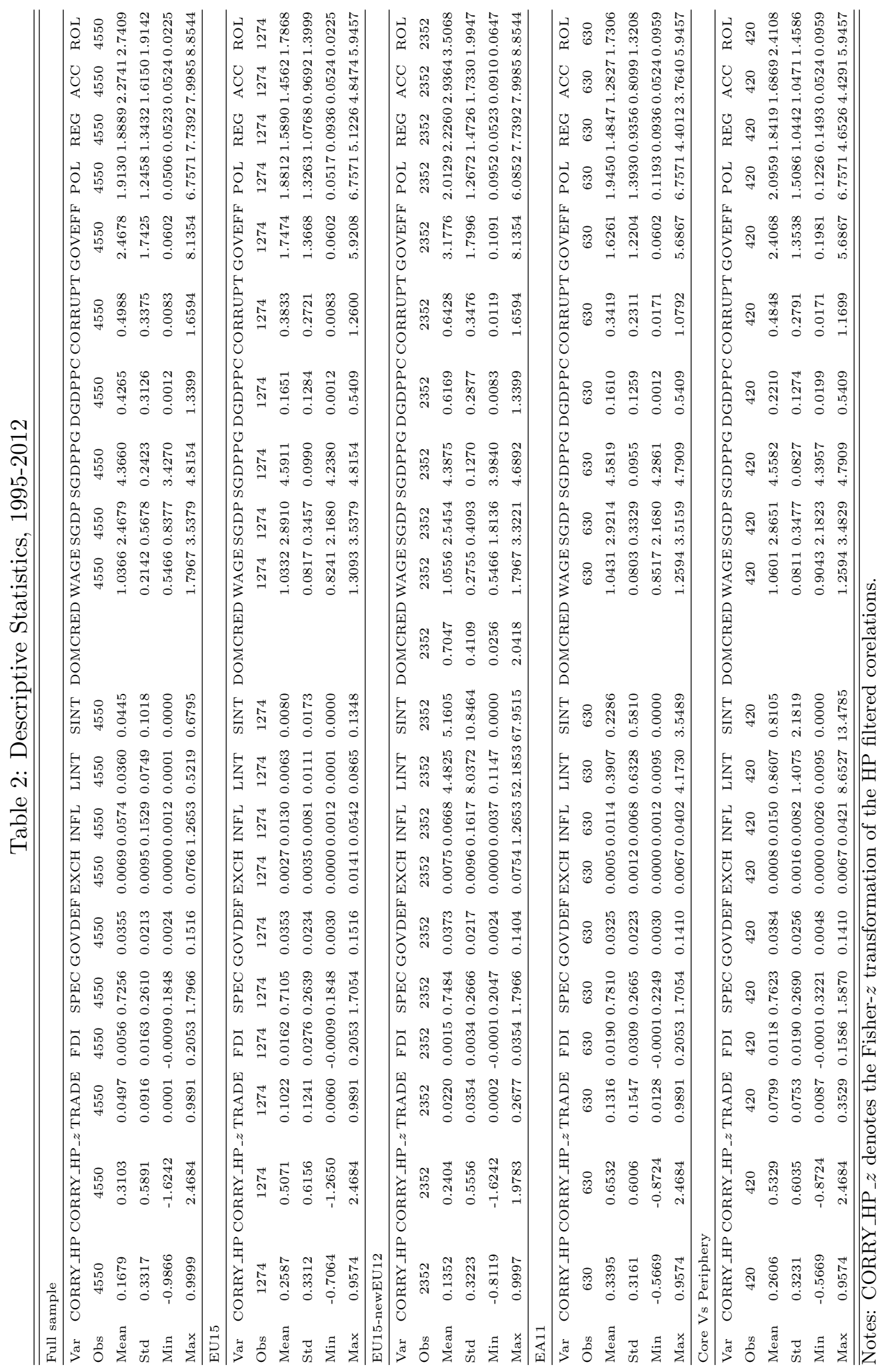


Table 3: Country groupings

\begin{tabular}{llllll}
\hline \hline & EU27 & EU15 & newEU12 & EA11 & Core $^{c}$ Vs Periphery $^{p}$ \\
\hline 1 & AUT & AUT & BGR & AUT & AUT $^{c}$ \\
2 & BEL & BEL & CYP & BEL & BEL $^{c}$ \\
3 & BGR & DNK & CZE & FIN & FIN $^{c}$ \\
4 & CYP & FIN & EST & FRA & FRA $^{c}$ \\
5 & CZE & FRA & HUN & GER & GER $^{c}$ \\
6 & DNK & GER & LVA & IRL & GRC $^{p}$ \\
7 & EST & GRC & LTU & ITA & IRL $^{p}$ \\
8 & FIN & IRL & MLT & LUX & ITA $^{p}$ \\
9 & FRA & ITA & POL & NED & LUX $^{c}$ \\
10 & GER & ROM & PRT & PRT & NED $^{c}$ \\
11 & GRC & LUX & SVK & ESP & PRT $^{p}$ \\
12 & HUN & PRT & SVN & & ESP $^{p}$ \\
13 & IRL & ESP & & & \\
14 & ITA & SWE & & & \\
15 & LVA & UK & & & \\
16 & LTU & & & & \\
17 & LUX & & & & \\
18 & MLT & & & & \\
19 & NED & & & & \\
20 & POL & & & & \\
21 & PRT & & & & \\
22 & ROM & & & & \\
23 & SVK & & & & \\
24 & SVN & & & & \\
25 & ESP & & & & \\
26 & SWE & & & & \\
27 & UK & & & & \\
\hline \hline
\end{tabular}


Table 4: Estimation Results of Simultaneous Equations, EU27, EU15 and EU15-newEU12

\begin{tabular}{|c|c|c|c|c|c|c|c|}
\hline & & \multicolumn{2}{|c|}{$\begin{array}{c}\text { EU27 } \\
1995-2012\end{array}$} & \multicolumn{2}{|c|}{$\begin{array}{c}\text { EU15 } \\
1995-2012\end{array}$} & \multicolumn{2}{|c|}{$\begin{array}{c}\text { EU15-newEU12 } \\
\text { 1995-2012 }\end{array}$} \\
\hline \multicolumn{8}{|l|}{ CORRY } \\
\hline & FDI & $-4.5353^{* * *}$ & $(0.7281)$ & $-11.4177^{* * *}$ & $(0.9027)$ & -0.0281 & $(4.225)$ \\
\hline & TRADE & $1.9093^{* * *}$ & $(0.1278)$ & $2.9258^{* * *}$ & $(0.1982)$ & $0.8222^{* *}$ & $(0.4060)$ \\
\hline & GOVDEF & $-2.1033^{* * *}$ & $(0.3497)$ & 0.9597 & $(0.6651)$ & $-8.0795^{* * *}$ & $(0.5149)$ \\
\hline & $\mathrm{EXCH}$ & $-2.5023^{* * *}$ & $(0.9308)$ & $-37.6312^{* * *}$ & $(4.3460)$ & 1.0827 & $(1.2669)$ \\
\hline & SPEC & $0.5125^{* * *}$ & $(0.0221)$ & $0.6643^{* * *}$ & $(0.0437)$ & 0.0341 & $(0.0421)$ \\
\hline & DGDPPC & $-0.0692^{* * *}$ & $(0.0280)$ & -0.0531 & $(0.1230)$ & $-0.0797^{*}$ & $(0.0432)$ \\
\hline & SGDPPC & & & & & $0.1220^{* * *}$ & $(0.0109)$ \\
\hline & $N$ & 4550 & & 1274 & & 2352 & \\
\hline & $R^{2}$ & 0.2292 & & 0.4161 & & 0.2066 & \\
\hline \multicolumn{8}{|l|}{ FDI } \\
\hline & CORRY & $-0.0014^{* * *}$ & $(0.0003)$ & $-0.0085^{* * *}$ & $(0.0008)$ & -0.0001 & $(0.0001)$ \\
\hline & TRADE & $0.1644^{* * *}$ & $(0.0016)$ & $0.2155^{* * *}$ & $(0.0032)$ & $0.0831^{* * *}$ & $(0.0013)$ \\
\hline & SPEC & $0.0020^{* * *}$ & $(0.0005)$ & $0.0108^{* * *}$ & $(0.0014)$ & $0.0015^{* * *}$ & $(0.0001)$ \\
\hline & DGDPPC & $0.0023^{* * *}$ & $(0.0005)$ & $0.0319^{* * *}$ & $(0.0037)$ & $-0.0016^{* * *}$ & $(0.0002)$ \\
\hline & WAGE & $-0.0041^{* * *}$ & $(0.0003)$ & $-0.0139 * * *$ & $(0.0011)$ & $-0.0003^{* *}$ & $(0.0001)$ \\
\hline & $N$ & 4550 & & 1274 & & 2352 & \\
\hline & $R^{2}$ & 0.5036 & & 0.6790 & & 0.4469 & \\
\hline \multicolumn{8}{|l|}{ TRADE } \\
\hline & CORRY & $0.0260^{* * *}$ & $(0.0016)$ & $0.0517^{* * *}$ & $(0.0034)$ & $0.0044^{* * *}$ & $(0.0010)$ \\
\hline & $\mathrm{EXCH}$ & -0.1191 & $(0.0755)$ & -0.4704 & $(0.3794)$ & $-0.2375^{* * *}$ & $(0.0493)$ \\
\hline & SPEC & $0.0313^{* * *}$ & $(0.0021)$ & $0.0447^{* * *}$ & $(0.0054)$ & $-0.0038^{* * *}$ & $(0.0013)$ \\
\hline & FDI & $5.0507^{* * *}$ & $(0.0502)$ & $4.1321^{* * *}$ & $(0.0667)$ & $9.0385^{* * *}$ & $(0.1371)$ \\
\hline & DGDPPC & $-0.0369^{* * *}$ & $(0.0040)$ & $-0.1039^{* * *}$ & $(0.0158)$ & $0.0301^{* * *}$ & $(0.0020)$ \\
\hline & REG & & & $-0.0037^{* * *}$ & $(0.0015)$ & $-0.0027^{* * *}$ & $(0.0004)$ \\
\hline & ROL & $0.0014^{* * *}$ & $(0.0006)$ & & & & \\
\hline & $\mathrm{N}$ & 4550 & & 1274 & & 2352 & \\
\hline & $R^{2}$ & 0.5629 & & 0.7322 & & 0.5209 & \\
\hline \multicolumn{8}{|l|}{ SPEC } \\
\hline & TRADE & $0.1488^{* *}$ & $(0.0582)$ & $0.2493^{* * *}$ & $(0.0837)$ & $2.1732^{* * *}$ & $(0.2957)$ \\
\hline & FDI & $0.5859^{*}$ & $(0.3255)$ & $1.5663^{* * *}$ & $(0.3738)$ & $22.1978^{* * *}$ & (3.1358) \\
\hline & REG & $-0.0134^{* * *}$ & $(0.0041)$ & $0.0254^{* * *}$ & $(0.0082)$ & & \\
\hline & $\mathrm{ACC}$ & $0.0070^{* *}$ & $(0.0035)$ & $0.0292^{* * *}$ & $(0.0088)$ & $0.1035^{* * *}$ & $(0.0046)$ \\
\hline & POL & & & & & $0.0989^{* * *}$ & $(0.0062)$ \\
\hline & SGDPPC & $0.1657^{* * *}$ & $(0.0018)$ & $0.1276^{* * *}$ & $(0.0033)$ & & \\
\hline & $\mathrm{N}$ & 4550 & & 1274 & & 2352 & \\
\hline & $R^{2}$ & 0.8857 & & 0.8882 & & 0.6943 & \\
\hline \multicolumn{8}{|l|}{ GOVDEF } \\
\hline & CORRY & $0.0069^{* * *}$ & $(0.0005)$ & $0.0068^{* * *}$ & $(0.0008)$ & $-0.0082^{* * *}$ & $(0.0008)$ \\
\hline & DGDPPC & $0.0522^{* * *}$ & $(0.0017)$ & $0.1189^{* * *}$ & $(0.0046)$ & $0.0519^{* * *}$ & $(0.0023)$ \\
\hline & LINT & $-0.0003^{* * *}$ & $(0.0000)$ & $0.0035^{* * *}$ & $(0.0005)$ & $-0.0003^{* * *}$ & $(0.0001)$ \\
\hline & GOVEFF & $0.0034^{* * *}$ & $(0.0003)$ & $0.0046^{* * *}$ & $(0.0004)$ & $0.0009^{* *}$ & $(0.0004)$ \\
\hline & $\mathrm{N}$ & 4550 & & 1274 & & 2352 & \\
\hline & $R^{2}$ & 0.5266 & & 0.6308 & & 0.6282 & \\
\hline \multicolumn{8}{|l|}{ EXCH } \\
\hline & CORRY & $-0.0006^{* * *}$ & $(0.0001)$ & $-0.0007^{* * *}$ & $(0.0001)$ & $-0.0004^{* * *}$ & $(0.0002)$ \\
\hline & GOVDEF & $0.0122^{* * *}$ & $(0.0026)$ & -0.0061 & $(0.0042)$ & $0.0163^{* * *}$ & $(0.0036)$ \\
\hline & DGDPPC & $0.0007^{* * *}$ & $(0.0002)$ & $-0.0032^{* * *}$ & $(0.0007)$ & $0.0021^{* * *}$ & $(0.0003)$ \\
\hline & SPEC & $0.0038^{* * *}$ & $(0.0002)$ & $0.0028^{* * *}$ & $(0.0002)$ & $0.0014^{* * *}$ & $(0.0002)$ \\
\hline & INFL & $0.0488^{* * *}$ & $(0.0006)$ & $0.0807^{* * *}$ & $(0.0121)$ & $0.0520^{* * *}$ & $(0.0006)$ \\
\hline & SINT & $0.0002^{* * *}$ & $(0.0000)$ & $0.0008^{* * *}$ & $(0.0001)$ & & \\
\hline & DOMCRED & & & & & $0.0018^{* * *}$ & $(0.0002)$ \\
\hline & $\mathrm{N}$ & 4550 & & 1274 & & 2352 & \\
\hline & $R^{2}$ & 0.8774 & & 0.4569 & & 0.8888 & \\
\hline \multicolumn{8}{|l|}{ DGDPPC } \\
\hline & TRADE & $-0.3695^{* * *}$ & $(0.0413)$ & 0.0113 & $(0.0217)$ & $1.5899^{* * *}$ & $(0.1347)$ \\
\hline & GOVDEF & $8.8835^{* * *}$ & $(0.1493)$ & $3.9428^{* * *}$ & $(0.1146)$ & $3.2579^{* * *}$ & $(0.1385)$ \\
\hline & FDI & & & & & $-8.9879^{* * *}$ & $(1.4270)$ \\
\hline & POL & $0.0652^{* * *}$ & $(0.0027)$ & $0.0114^{* * *}$ & $(0.0021)$ & & \\
\hline & $\mathrm{ROL}$ & & & & & $0.1124^{* * *}$ & $(0.0037)$ \\
\hline & CORRUPT & & & & & $0.0901^{* * *}$ & $(0.0220)$ \\
\hline & $\mathrm{N}$ & 4550 & & 1274 & & 2352 & \\
\hline & $R^{2}$ & 0.5764 & & 0.5541 & & 0.9185 & \\
\hline \multirow{3}{*}{\multicolumn{2}{|c|}{$\begin{array}{l}\text { Country fixed-effects } \\
\text { Time fixed-effects } \\
\text { Country-specific } \\
\text { time trends }\end{array}$}} & \multicolumn{2}{|c|}{ YES } & $\mathrm{YE}$ & & $\mathrm{YE}$ & \\
\hline & & $\mathrm{YE}$ & & YE & & $\mathrm{YE}$ & \\
\hline & & YE & & YE & & $\mathrm{YE}$ & \\
\hline
\end{tabular}

Notes: Standard errors in parenthesis. ${ }^{* * *},{ }^{* *}$ and ${ }^{*}$ łhnote significance at $1 \%$ level, $5 \%$ level and $10 \%$ level, respectively. All estimations with time specific effects. 
Table 5: Estimation Results of Simultaneous Equations, EA11 and Core Vs Periphery

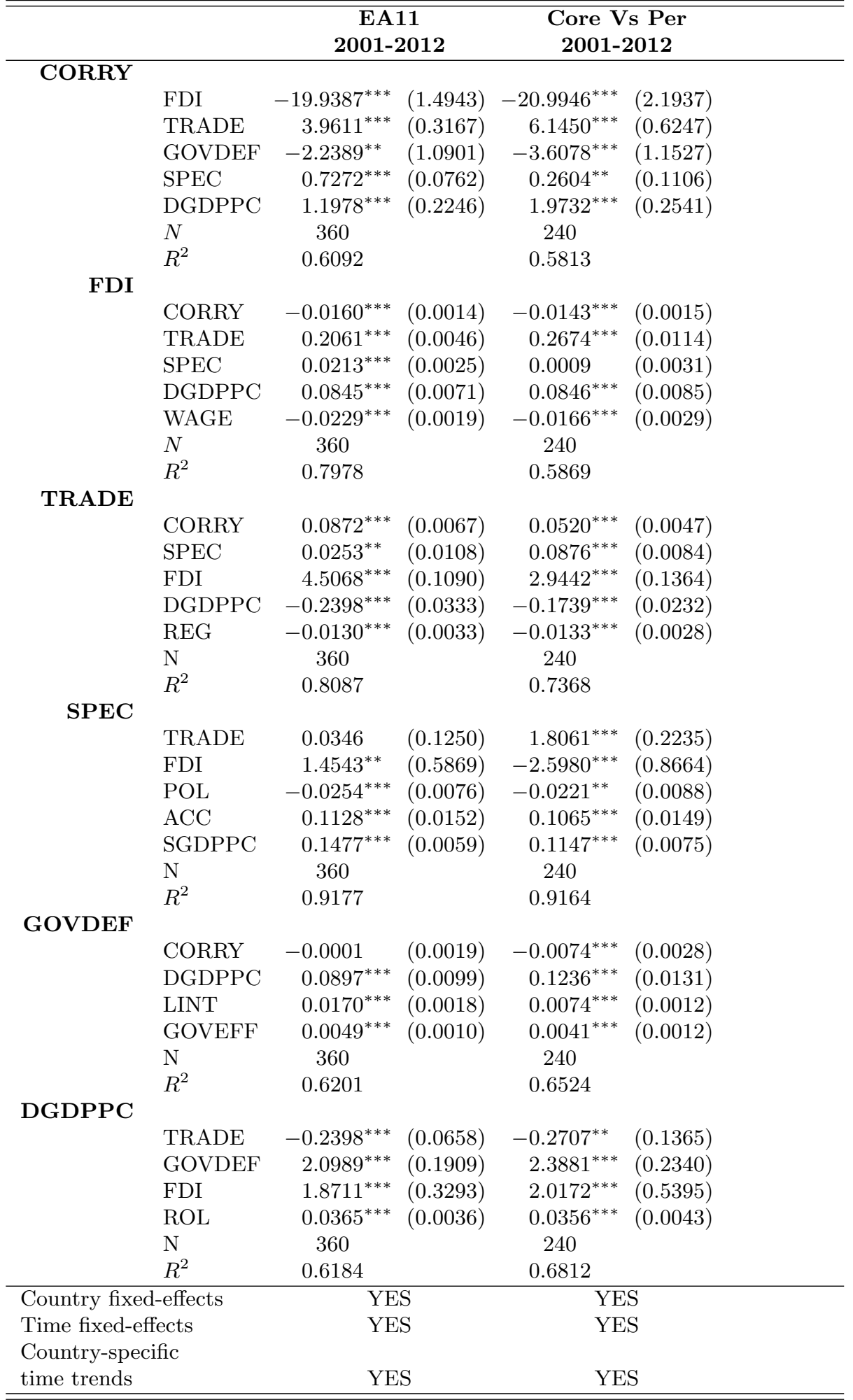

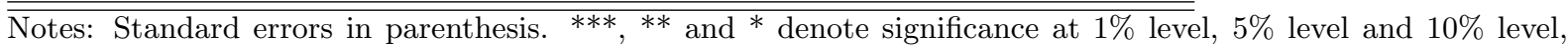
respectively. All estimations with time specific effects. 


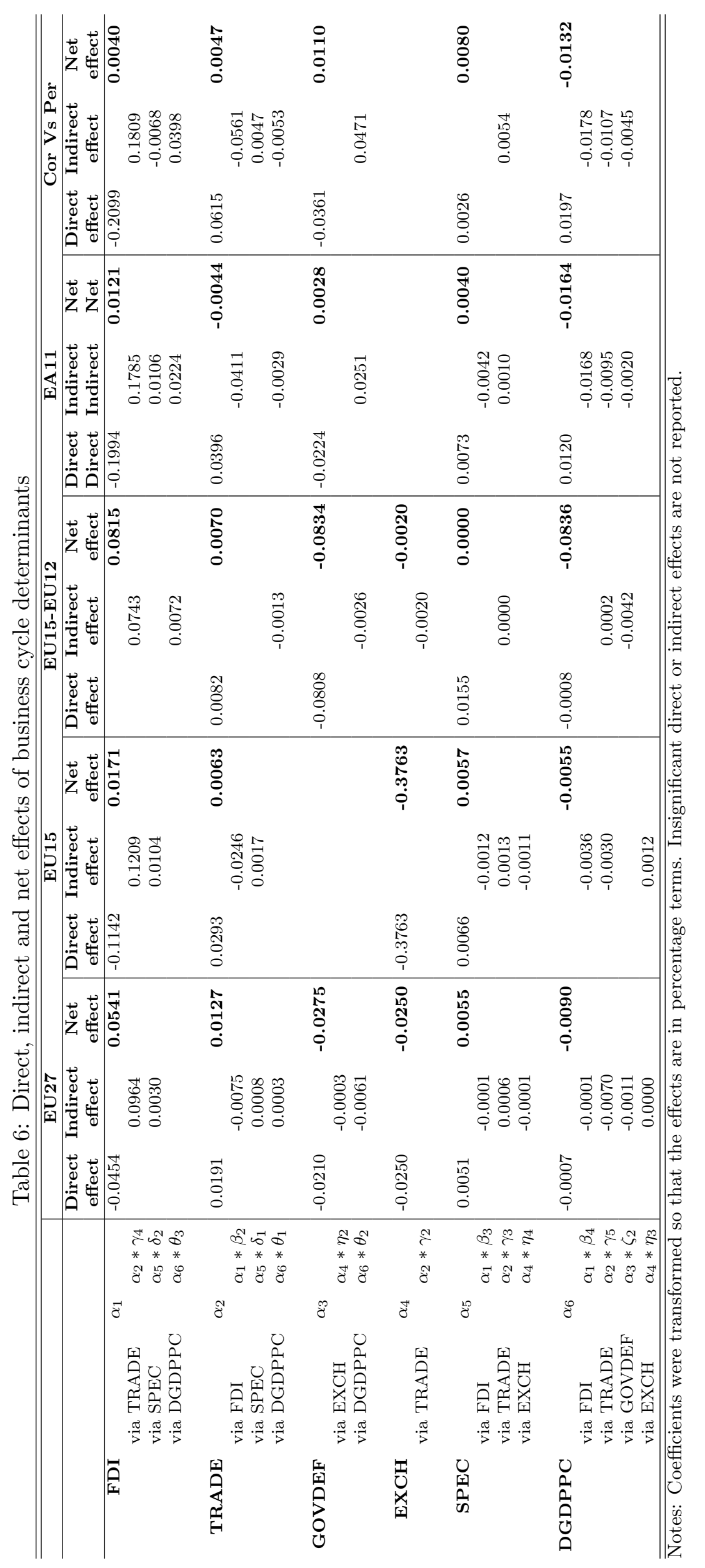

